\title{
Herd behavior of pension funds in sovereign bond investments
}

\author{
Ian Koetsier ${ }^{1}$ and Jacob A. Bikker ${ }^{2 *}$ \\ ${ }^{1}$ Utrecht School of Economics, Utrecht University Faculty of Law Economics and Governance, Utrecht, The Netherlands and \\ ${ }^{2}$ Economic Policy Division, Research Department, De Nederlandsche Bank NV, Amsterdam, Noord-Holland, \\ The Netherlands \\ ${ }^{\star}$ Corresponding author. Email: j.a.bikker@dnb.nl
}

(Received 25 March 2020; revised 4 March 2021; accepted 19 March 2021; first published online 11 May 2021)

\begin{abstract}
This study investigates herd behavior exhibited by pension funds in the sovereign bond market before, during and after the European debt crisis. It uses unique monthly data on sovereign bond holdings of pension funds and transactions between December 2008 and December 2014. The dataset covers 67 large Dutch pension funds that invest in bonds from 109 countries. We find evidence of intensive herd behavior of Dutch pension funds in sovereign bonds. We also distinguish between European countries which suffer from the European debt crisis, such as Cyprus, Greece, Ireland, Italy, Portugal and Spain, and those that have not. We find high sell herding and low buy herding for the crisis countries during the European debt crisis, whereas in the non-crisis period their herd behavior does not differ substantially from that in non-crisis countries. When we control for institutional, macroeconomic, financial market and pension fund factors, sell herding in crisis countries is still significantly higher. However, we find no evidence of destabilizing behavior with respect to bonds of crisis countries during the European debt crisis.
\end{abstract}

Key words: (De-)stabilizing; herd behavior; institutional, macroeconomic and financial market factors; pension funds; sovereign bonds

JEL codes: G11; G15; G18; G23

\section{Introduction}

Institutional investors are sometimes blamed for aggravating the European debt crisis. The Bank of England and the Procyclicality Working Group (2014) notes that current pension funds' practices result in pension fund herding: investing in the same assets at the same time. Because pension funds manage a substantial part of global government bonds, their behavior is likely to have a significant impact on financial market sentiment (De Haan and Kakes, 2011). Pension funds' behavior may move securities away from their price equilibrium and induce abnormal volatility (Chang et al., 2000). Their behavior potentially contributes to procyclicality, amplifying asset price or economic cycles, potentially leading to market bubbles and financial crises. Whether this occurs in practice remains the subject of heated debate, both in academic and in policy circles. Institutional investors are often considered long-term investors trading on fundamentals. This type of investment behavior has a stabilizing effect on financial markets. In itself, the occurrence of herding is not necessarily destabilizing as it can be the result of the incorporation of new information.

Our study investigates the behavior of Dutch pension funds in the sovereign bond market during tranquil and crisis periods. The Dutch second pillar of the pension system is relatively mature, and the pension 
systems in other countries move in this direction due to pension reform and population aging. We use unique data on the holdings of Dutch pension funds provided by De Nederlandsche Bank (DNB), the Dutch central bank. The monthly pension fund holdings data break down into sales and purchases, revaluations, exchange rate and other adjustments. Thus, we directly observe sales and purchases and other factors influencing the value of the pension fund's sovereign bond holdings. Most herding studies estimate purchases and sales from the change of pension fund's holdings corrected by a market index. Contrary to our study, these studies do not directly observe purchases and sales by pension funds.

Our study investigates herding in direct long-term sovereign debt (of 1 year or more) because of its significance in pension funds' investment portfolios. Focusing on direct holdings assures that we do not observe herd behavior that stems from investments of various pension funds in the same mutual fund. It allows us to determine the drivers of herd behavior, without putting a disproportional weight on the decisions of external asset managers. In addition, we choose not to include short-term holdings in our analysis because these holdings might be used for liquidity management reasons, and not a long-term investment. The direct long-term sovereign holdings represent a substantial and growing part of the Dutch pension funds' holdings. It grew to EUR 164 billion in December 2014 from EUR 89 billion in December 2008. Furthermore, the direct long-term sovereign holdings account for $>50 \%$ of total sovereign holdings of Dutch pension funds. Notice that the total sovereign holdings include short as well as long-term bonds, and direct and external sovereign holdings.

This study aims to establish whether pension funds exhibit herd behavior in long-term sovereign debt investments and to identify the drivers behind herd behavior. Furthermore, it explores whether herding ultimately has a stabilizing or destabilizing effect on the sovereign bond markets. When herd behavior leads to quicker incorporation of price information, this behavior could be stabilizing. This article makes several contributions to the herding literature. It investigates the herd behavior of pension funds in long-term sovereign bonds in the international setting. In addition, most empirical studies investigate herd behavior by mutual funds. This study contributes to a small number of herding studies focusing on pension funds (e.g., Lakonishok et al., 1992; Voronkova and Bohl, 2005; Jame, 2011; Broeders et al., 2021). This is important as pension funds represent a considerable proportion of institutional investors. Furthermore, most studies investigate herd behavior in equity investments (Lakonishok et al., 1992; Voronkova and Bohl, 2005; Jame, 2011), whereas bonds also generally make up a considerable part of a pension fund's portfolio. This study sheds light on the herd behavior during both the European sovereign debt crisis and normal times. Our results improve the understanding that policymakers have of the trading behavior of pension funds.

Our article is structured as follows. Section 2 reviews the literature and Section 3 explores the Dutch pension system. Section 4 explains the methodology and data used, whereas Section 5 presents our results. Section 6 lists our conclusions.

\section{Literature review}

Herding in financial markets occurs when market participants contemporaneously trade in the same direction and/or their behavior converges to the market consensus (Galariotis et al., 2015). This happens over a specific period, known as the herd interval.

Herding can be intentional or spurious in nature, according to Holmes et al. (2013), although not all reasons for herd behavior might be mutually exclusive. In intentional herding models, there is an asymmetry between market participants in, for example, knowledge and/or past performances. Reputational considerations are believed to be a driver of herd behavior. Managers follow their high-ability counterparts, for example, guru investors (Trueman, 1994), which they regard as having superior knowledge compared to themselves. Asset managers also stay close to the pack because underperformance may adversely impact their remuneration or their career prospects (Scharfstein and Stein, 1990; Rajan, 2006). Informational herding occurs when investors infer information from other investors' trades (Banerjee, 1992; Bikhchandani et al., 1992; Sias, 2004). In this case, investors mimic the trading behavior of others, which they deem to be informed. 
Spurious herding occurs unintentionally due to similarities in the information investors receive, the similar interpretation of this information or similar investment preferences. Investigative herding occurs when market participants act on the same signals, for instance, credit rating changes and/or Bloomberg data (Froot et al., 1992; Hirshleifer et al., 1994). Teh and DeBondt (1997) indicate that the investors also similarly interpret this information because of the mental frames that are socially and professionally shared. Asset managers often have similar characteristics (e.g., their education and their social background). Characteristics herding occurs when investors trade based on the specific characteristics of an asset (Falkenstein, 1996; Holmes et al., 2013). This is not limited to assets; herding might also occur due to similar investment styles. Many investors with a similar investment style lead to trading in a similar direction at roughly the same time (e.g., Bennett et al., 2003).

We are particularly interested in investment behavior in times of crisis. If herding is aggravated during crises, this may cause high societal costs. ${ }^{1}$ Most studies investigate herd behavior in equity investments by mutual investments during crises for emerging economies. Kaminsky et al. (2004) investigate 13 Latin American equity funds between April 1993 and January 1999. They find that momentum trading behavior by Latin American equity funds is aggravated during crises. Kim and Wei (2002) study trading behavior in South Korea from December 1996 to June 1998. They also find herding and positive feedback trading for Korea at the time of the crisis. Hsieh et al. (2011) broaden the scope to 12 Asian markets between 1996 and 2004, and find more pronounced herding in countries during and after a crisis. In contrast, Choe et al. (1999) do not find convincing evidence of herd behavior during the Asian crisis. Hwang and Salmon (2004) also point in this direction. Borensztein and Gelos (2000) find no significant difference between the prevalence of herding in crisis and in tranquil times. ${ }^{2}$ There is mixed evidence on the effect of a crisis on the intensity of herd behavior. Gelos and Wei (2005) attribute these differences to country characteristics. They show for 137 global emerging markets and international equity funds that these funds have a higher propensity to exit non-transparent countries during crises.

There are few studies on herd behavior for bond investments, which mostly use data of mutual bond funds. Cai et al. (2019) find that the corporate bond herding measure is 0.1 on average for US bond funds. The mean herding measure is 0.1 (It implies that if half of the changes in the sovereign bond market are increases, and the other half decreases, then $60 \%$ of the bond investors were changing their holdings of average bond investment in one direction and $40 \%$ in the opposite direction.). The Lakonishok, Shleifer and Vishny (LSV) herding measure is often close to 0.03 for equity investments in the United States (Lakonishok et al., 1992; Grinblatt et al., 1995; Jame, 2011). More recently, Xiao (2015) uses data from foreign and domestic equity and (sovereign as well as corporate) bonds of mutual funds for Mexico. Her findings show that foreign funds herd more intensively during periods of market stress. Broeders et al. (2021) also find support for the information, regulation and reputation motives of herd behavior by Dutch pension funds for bond investments. Only a few studies investigate sovereign bond herding. Xiao (2007) investigates the behavior of 44 emerging market bond funds that specialize in sovereign bonds between May 2003 and December 2003. This study shows that bond funds chase bonds with high past returns and yields. Raddatz and Schmukler (2013) examine herd behavior for multiple asset classes, amongst them, domestic government bonds for the period between 1996 and 2005. On average, they find herding for domestic government bonds. However, the use of domestic bonds may lead to underestimation of herd behavior in sovereign bonds, due to information advantages for domestic bond investments. This study focuses on all direct long-term sovereign bond holdings of Dutch pension funds, which include holdings in 109 countries.

\footnotetext{
${ }^{1}$ Koetsier and Bikker (2018) provide an extensive review of the empirical literature on herd behavior.

${ }^{2}$ They investigate between 382 and 467 equity funds for investments in Asia, Latin America, Europe, the Middle East and Africa between January 1996 and March 1999.
} 


\section{The Dutch pension system}

The Dutch pension system is a three-pillar system. ${ }^{3}$ Our study focuses on the second pillar, which consists of company-specific and sector-specific pension funds that invest in employee and employer contributions upfront. Their holdings accumulate over time and form part of their members' retirement income. The holdings of all second pillar pension funds came to EUR 1.471 billion at the end of $2019 .{ }^{4}$ This represents $187 \%$ of Dutch GDP in that year. Their size results from the construction of the second pillar, which is officially quasi-mandatory.

Pension fund investments are relatively unrestricted compared to other countries. This is attributable to the Dutch regulation framework, which is based on the prudent person rule. Article 135 of the Dutch Pensions Act states that a pension fund's investment must be in the best interests of active and former members and pensioners. The absence of legal restrictions for sovereign bond investments gives them the opportunity to exhibit herd behavior without any a priori influence of legal restrictions on their investment decisions. On the one hand, this might enable them to herd more intensively than when their behavior was limited by legal restriction. On the other hand, it gives them more options for investment which might reduce herd behavior in particular assets. Voronkova and Bohl (2005), for example, find that there are investment limits on equity investments for Polish pension funds. This steers pension funds towards the same assets, aggravating herd behavior.

\section{Methodology and data}

\subsection{Methodology}

We adopt the Lakonishok et al. (1992) (LSV) herding measure, which is widely used in other herding studies (e.g., Grinblatt et al., 1995; Voronkova and Bohl, 2005; Cai et al., 2019). The measure represents the balance or imbalance between the buys and sells of bonds from country ( $i$ ) during a specific month $(t)$. Note that pension funds are the entities that are trading sovereign bonds in a particular country ( $i$ ). The LSV herding measure is adjusted to take into account an imbalance between buys and sells which merely occur by random chance (e.g., an odd number of trades). As a consequence, the herding measure is positive when there is more trading in a specific direction than one would expect if trading is random and independent. When the LSV herding measure is zero, it indicates that pension funds' trading is random and independent. The LSV herding measure is unable to distinguish between spurious herding and intentional herding, but we agree with the International Monetary Fund (2014) that the measure provides indicative evidence of 'true' herding. Following LSV, we define the herding measure as:

$$
H M_{i t}=\left|p_{i t}-p_{t}\right|-A F_{i t},
$$

where

$$
p_{i t}=\frac{B_{i t}}{B_{i t}+S_{i t}}
$$

and

$$
p_{t}=\frac{\sum_{i=1}^{n} p_{i t}}{n},
$$

$B_{i t}$ is the number of pension funds that are net buyers of long-term sovereign bond from country $(i)$ in month $(t)$, whereas $S_{i t}$ indicates the number of pension funds that are net sellers of long-term

\footnotetext{
${ }^{3}$ An earlier version of this paper, Koetsier and Bikker (2017), provides a more detailed explanation of the Dutch pensions system.

${ }^{4}$ Data retrieved from De Nederlandsche Bank.
} 
sovereign bonds from country $(i)$ in a particular month $(t)$. Together $\left(B_{i t}+S_{i t}\right)$ give the total number of pension funds buying and selling in country $(i)$ in month $(t) . p_{i t}$ gives the proportion of buys by pension funds for country $(i)$ in month $(t)$, so this ratio varies by month and by country. Equation (3) shows $p_{t}$ which is the average proportion of Dutch pension funds buying long-term sovereign bonds in month $(t)$. The number of pension funds purchasing and selling sovereign bonds may vary each month. $n$ is the number of countries in which pension funds trade in a particular month. Note that positive cash inflow (contributions minus pension benefit payments) is corrected by $p_{t}$. The difference between these proportions is given in absolute terms, so the first component of equation (1) is always positive.

$$
A F_{i t}=E\left[\left|p_{i t}-p_{t}\right|\right]
$$

$A F_{i t}$ represents the adjustment factor ${ }^{5}$ and $E$ denotes the expectation operator. ${ }^{6}$ The expected outcome is the sum of all possible outcomes times their probability of occurring. Following the herding literature, we assume $p_{t}$ to equal the proportion of buys by all Dutch pension funds of long-term government bonds in period $(t)$. Herd behavior displayed by pension funds differs for each month and each destination country.

Some studies show that different behavior may apply to sell and buy herding. Since we investigate extreme market circumstances, phenomena like fire-sales may play a role. Following Wermers (1999), we use modified herding measures to identify sovereign bonds of countries that had a higher (or lower) proportion of buyers than the all-countries average sovereign bond trading during the same month. Equations (5) and (6) show the buy and sell herding measures, respectively, $B H M_{i t}$ and $S H M_{i t}$ :

$$
\begin{gathered}
B H M_{i t}=H M_{i t} \mid p_{i t}>p_{t}, \\
S H M_{i t}=H M_{i t} \mid p_{i t}<p_{t} .
\end{gathered}
$$

Following Wermers (1999), the adjustment factor (equation (4)) is recalculated conditioned on $p_{i t}>p_{t}$ and $p_{i t}<p_{t}$ for $B H M_{i t}$ and $S H M_{i t}$, respectively. The null hypothesis remains that pension funds trade random and independent.

The financial literature identifies some limitations of the LSV herding measure, and we aim to address these issues. First, Frey et al. (2014) note that the LSV herding measure is potentially downward biased and propose the Frey, Herbst and Walter (FHW) herding measure. However, Bellando (2010) shows that the FHW herding measure is only accurate under very strong assumptions, and otherwise it is upward biased. Our LSV herding measures can be regarded as a lower end of 'true' herding, whereas the FHW herding measures likely overestimates 'true' herding. We primarily use the LSV herding measure as it is more established in the herding literature and it allows for comparisons of our findings with that of previous studies. We also calculate the FHW measure to allow for comparison between the LSV and FHW herding measures. We follow Frey et al. (2014) by taking the square root of the aggregated FHW herding measure to make its level comparable to that of the LSV

\footnotetext{
${ }^{5}$ Among other aspects, the $A F_{i t}$ also corrects the LSV measure when there are only a small number of trades. In addition, it corrects for the possibility that the number of pension funds' trades cannot equal the proportion of buys by all Dutch pension funds of long-term government bonds in period $\left(p_{t}\right)$.

${ }^{6}$ Independent trading outcomes are expected to follow a binomial distribution, and Equation (4.2) shows how to calculate the probability of occurrence.
}

$$
\begin{gathered}
N_{i t}=B_{i t}+S_{i t} \\
b\left[N_{i t} ; B_{i t}, p_{t}\right]=\left(\begin{array}{c}
N_{i t} \\
B_{i t}
\end{array}\right) p_{t}^{B_{i t}}\left[1-p_{t}\right]^{N_{i t}-B_{i t}}
\end{gathered}
$$

The adjustment factor is the sum of all outcomes times the probability of occurrence. 
herding measure. Second, Bikhchandani and Sharma (2000) note that the LSV herding measure fails to account for the size of the transaction. We apply a minimum sufficient size for transactions as suggested by Andreu et al. (2014) and Frey et al. (2014). We only use purchase and sell transactions that are larger than EUR 0.5 million. This excludes the smaller transactions. Furthermore, we weigh the herding measure by transaction size, which considers all transactions. Third, the LSV herding measure is unable to capture the inter-temporal trading pattern (implementation of trading strategies over multiple months), as suggested by Sias (2004). Therefore, we identify position continuing trades, which are observations where the direction of trade has not changed in the subsequent month. We disregard these observations. Fourth, Lobão and Serra (2007) note that the LSV herding measure does not identify the underlying cause of herding. We think that the causes in theoretical literature are not mutually exclusive contrary to the suggestion of Lobão and Serra (2007). We do investigate the determinants of herd behavior such as economic and financial circumstances. Fifth, an important underlying assumption of the LSV herding measure is the no short-selling constraint mentioned by Wylie (2005). Wylie (2005) notes that the likelihood of sell herding is lower than buy herding, as sell herding requires pension funds to have sovereign bond holdings first. To account for this issue, we apply robustness checks where we only investigate buy and sell herding in sovereign bonds of countries where pension funds have such holdings in the previous month. This enables pension funds to sell these holdings, and exhibit sell herding. Sixth, Wylie (2005) notes that the ex-ante probability of a fund manager selling or buying an asset depends exclusively on the extent of herd behavior. Low liquidity in the sovereign bond market may delay order executions. Consequently, herd behavior can result from illiquidity in the sovereign bond market. As a consequence, pension funds might be unable to sell their sovereign bonds, especially markets with low trading volumes such as frontier markets. We use the number of trades as an indication of the liquidity of the sovereign bond market imposing a minimum number of $3,5,10$ or 15 trades. This means that at least 3, 5, 10 or 15 pension funds trade in country $(i)$ during month $(t)$. The number of trades includes buy and sell transactions; here we make no distinction between those. In this way, we are able to investigate whether illiquidity might have an effect on herd behavior.

We conduct pooled ordinary least squares (OLS) and least-squares dummy variable (LSDV) ${ }^{7}$ regressions to identify the causes of herd behavior in the sovereign bond market. ${ }^{8,9}$ We prefer the use of LSDV because it enables us to connect to other herding studies and allows us to estimate the impact of factors identified by the herding theory. Furthermore, there are also some merits of using LSDV estimations over OLS. ${ }^{10,11}$ First, it enables us to use the monthly data on holdings and transactions whereas cross-section uses the average across all months. Second, it accounts for unobserved country fixed effects. Due to the different behavioral effects on the buy and sell side, we use the buy $\left(B H M_{i t}\right)$ and sell herd measure $\left(S H M_{i t}\right)$ proposed by Wermers (1999) as our dependent variables. Our buy herd regression is specified as follows (the sell herd regression only differs in terms of

\footnotetext{
${ }^{7}$ Following Raddatz and Schmukler (2012), we estimate the fixed effect using the LSDV method. Our sample includes 73 months, which allows us to estimate our fixed effects specification with a very small asymptotical bias (the bias is of the order $1 / T)$. The average time period per country equals 66.1 months.

${ }^{8} \mathrm{We}$ also use truncated regressions as a robustness check because the values of the dependent variable can only vary within a certain range. The truncation takes place below -0.5 and above 0.5 . As the results are relatively similar, they are not included in this article, but they are available on request from the authors.

${ }^{9}$ We apply first-differences estimators, because these estimators only require weak exogeneity. This is easier to satisfy than strict exogeneity for within-estimators. However, the herding literature identifies the levels of the variables as important drivers of herding. In a within-estimation, endogeneity problems are not always sufficiently dealt with by lagging variables. In the quintile analysis, we use non-lagged pension funds variables and obtain highly similar results as in our regression analysis. The lagged variables prove to be of minor interest for our main results.

${ }^{10}$ Using fixed effects, we reduce the possible bias from the country fixed effects. To further deal with the data structure, we clustered at the country level and at a monthly basis.

${ }^{11}$ We conduct the Harris and Tzavalis (1999), Im et al. (2003) and Pesaran (2007) panel stationarity tests and adjust the data to cover data gaps.
} 
the dependent variable):

$$
B H M_{i t}=\alpha+\gamma_{1}^{\prime} M E C_{i t}+\gamma_{2}^{\prime} F M S_{i t}+\gamma_{3}^{\prime} P F C_{i t-1}+\varphi_{i}+\theta_{t}+\nu_{i t}
$$

We divide our variables into three broad categories, i.e., indicators of macroeconomic circumstances (MEC), financial market sentiment (FMS) and pension fund characteristics (PFC). ${ }^{12}$ The macroeconomic and financial indicators change by country $(i)$ and month $(t) .{ }^{13}$ The macroeconomic indicators include inflation, the current account balance, exchange rate movements, GDP growth, general government debt, the size of the government bond market, the unemployment rate, net lending by the government, Standard \& Poor's (S\&P) credit ratings and outlook. ${ }^{14}$ These variables are all believed to influence the appetite for investing in government bonds and reflect the viability of the underlying economy. In addition, it is to be expected that most pension fund managers have direct access to this information. When the variables are not available on a monthly basis, we use the last available value for the missing observation.

The financial indicators capture the trend of share prices, CDS spreads, the VIX index and longterm government bond yields, among others. Note that the VIX index changes only over time and not at the country level as it is a global index. ${ }^{15}$ The financial indicators include local as well as global trends in the financial markets. A local phenomenon is the movement of the share price on the domestic stock exchange and a global phenomenon is the change of the VIX index.

In our regression analysis, pension fund characteristics are averaged at the country level. Following Bikker et al. (2007), we include the pension fund characteristics with a lag to limit endogeneity problems. The vector PFC includes the logarithm of the size of the pension fund to incorporate the effect of in-house analyzing capacity. This study uses the logarithm of the pension fund's size to ensure that the two largest funds do not disproportionally influence our results. The distance to the government bond strategic asset allocation is included to account for additional purchases or sales in order to meet the strategic asset allocation. The actual and strategic asset allocation is part of our dataset. Trading can also result from a pension fund's risk preference. We estimate risk preference by the ratio of equity and private equity holdings to fixed-interest investments. The inclusion of the funding ratio is motivated by the fact that it may influence the risk appetite and risk taking of a specific pension fund (e.g., gamble for redemption ${ }^{16}$ ). We also account for the preference of relative high past returns by using the ratio between the returns on fixed-interest investments and total returns. In this way, we can account for return-chasing behavior in the pension fund's asset portfolio. Following Calvo and Mendoza (2000), this study also aims to establish whether the share of a pension fund's sovereign holdings in a specific country influences herd behavior. Small sovereign bond holdings are relatively costly if there are country-specific fixed costs for bond investments. This makes mimicking behavior a rational choice.

The inclusion of these variables allows us to test for the different drivers of herd behavior. The specification does not assign different weights to the various explanations and allows for the simultaneous occurrence of multiple explanations. We also examine the influence of the financial market and macroeconomic circumstances on herd behavior (e.g., a crisis or a tranquil period).

\footnotetext{
${ }^{12}$ The sources and definitions for all variables are available in an earlier version of this paper, Koetsier and Bikker (2017).

${ }^{13}$ When we construct all possible country-month combinations, we find that Dutch pension funds are not trading in $22 \%$ of the possible country-month combinations.

${ }^{14}$ According to the sovereign rating literature, there are two major rating agencies, being S\&P and Moody's. We decided to use S\&P as it is considered to be the lead rating agency. Gande and Parsley (2014) show this using the Cooper et al. (2001) leader-follower ratio.

${ }^{15}$ The VIX index is often interpreted as a measure of global risk aversion (International Monetary Fund, 2014).

${ }^{16}$ Dutch pension law has several regulations regarding funding ratios. When funding ratios are too low over a five years period, pension funds must lower their pension benefits. A side-effect might be that pension funds with low funding ratios take (one-off) additional risks to improve their funding ratios to prevent a lowering of pension benefits, the so-called gambling for resurrection.
} 


\subsection{Data}

This study uses two unique datasets of DNB on the holdings of Dutch pension funds. The balance of payments statistics dataset includes monthly transaction data of Dutch pension funds where individual long-term sovereign bonds are aggregated on the country level for each pension fund. It includes value changes divided into net purchases or sales (adjusted for accrued interest), price movements, exchange rate adjustments and other changes. This makes our study unique as we do not need to estimate sales and purchases from holdings data. ${ }^{17}$ The data also includes the holdings at the beginning and end of a period and the destination country of investment at the country level per pension fund. We have transaction data for 67 pension funds on sovereign bond investments in up to 109 countries. Our data covers the period between December 2008 and December 2014, in a total of 73 months. Together we have 60,626 country-pension fund-month combinations. The strength of our data is their high (monthly) frequency. DNB's supervisory dataset, our second unique dataset, includes pension fund-specific information. We distill the funding ratio, strategic asset allocation, fund size, and other characteristics from this dataset. Further, we add data on macroeconomic and financial market circumstances, obtained from the World Bank, S\&P, different central banks and the OECD. Our study focuses on sovereign bond holdings of pension funds. This allows us to investigate the investment behavior of pension funds during the European debt crisis, and to assess their behavior during tranquil and crisis times and compare the two. Table 1 provides summary statistics of the control variables.

Dutch pension funds held long-term sovereign bonds in 109 countries (Figure 1). This provides for a broad geographic spread, substantial institutional differences and variation in economic circumstances. The largest direct sovereign bond investments are EUR 53 billion in German and EUR 43 billion in Dutch sovereign bonds at the end of 2014. Although the investments in these countries account for a large part of Dutch pension funds' sovereign bond holdings, there are still substantial investments in other countries (totaling EUR 68 billion), including non-European countries. Note that herd behavior is about trading behavior and the size of the investments is not the subject of investigation. The purchase and sell transactions are spread even more equally over the world than sovereign bond investments. The number of transactions is equally divided between advanced economies (50\%) and emerging and developing economies (50\%). Figure 2 shows the geographical spread of sovereign bond transactions in our dataset. It reveals that pension funds' trades are spread all across the world. Figure 3 illustrates that Dutch pension funds trade in almost all countries every month.

Around $75 \%$ of the sovereign bond investments are denominated in euros. The non-euro denominated bonds are for more than $75 \%$ denominated in major currencies (US dollars, Japanese yen or British pound). The currency risks of these major currencies are hedged for $\sim 75 \%$, and other currencies are generally fully hedged. The main reason for minimizing the currency exposure is the Dutch pension law. It obliges pension funds to hold considerably more capital when they do not hedge their currency exposure.

We choose not to include the trading of short-term sovereign bonds because these trades can result from liquidity considerations, and not from a long-term investment decision. Additionally, we do not include the holdings of pension funds at external asset managers, as observed following behavior can be the result of a similar investment strategy of the external asset manager. Furthermore, we want to develop an understanding of what drives herd behavior, and including external asset managers which invest in the same manner for multiple pension funds can put disproportionate weight on the determinants that they use in their investment decisions.

For several reasons, our study provides conservative estimates of true pension fund herd behavior. First, our analysis only includes direct investments of Dutch pension funds based on its own decisions.

\footnotetext{
${ }^{17}$ We adjust for the accrued interest by imposing a minimum net purchase because a net purchase can occur due to accrued interest. The accrued interest is added as a purchase in the balance of payments statistics. We adjust for this by imposing a minimum of the purchase equal to the prevailing long-term interest rate in that particular country.
} 
Table 1. Summary statistics of MEC, FMS and PFC indicators

\begin{tabular}{|c|c|c|c|c|c|}
\hline & Observations & Mean & Std. Dev. & Min & Max \\
\hline \multicolumn{6}{|l|}{ Macroeconomic circumstances } \\
\hline Inflation & 60,622 & 1.94 & 2.58 & -6.60 & 30.37 \\
\hline Current account & 60,605 & -0.52 & 6.55 & -38.10 & 32.60 \\
\hline Exchange rate, change & 57,742 & 0.11 & 2.18 & -11.08 & 67.98 \\
\hline GDP growth & 60,605 & 1.21 & 3.30 & -13.10 & 17.66 \\
\hline General government debt & 60,399 & 61.94 & 32.86 & 4.46 & 244.90 \\
\hline Logarithm of the sovereign bond market & 38,538 & 26.31 & 1.81 & 17.81 & 30.48 \\
\hline Net government lending & 60,605 & -3.68 & 4.41 & -32.42 & 20.49 \\
\hline Unemployment rate & 56,109 & 8.53 & 4.74 & 0.45 & 33.29 \\
\hline Control of corruption & 60,626 & 0.57 & 1.07 & -1.57 & 2.52 \\
\hline Government effectiveness & 60,626 & 0.69 & 0.90 & -1.26 & 2.27 \\
\hline Political stability and absence of violence/terrorism & 60,626 & 0.23 & 0.87 & -2.81 & 1.49 \\
\hline Regulatory quality & 60,626 & 0.71 & 0.84 & -1.81 & 2.23 \\
\hline Rule of law & 60,626 & 0.58 & 1.03 & -1.89 & 2.12 \\
\hline Voice and accountability & 60,624 & 0.61 & 0.84 & -1.66 & 1.76 \\
\hline \multicolumn{6}{|l|}{ Financial market sentiment } \\
\hline Credit rating & 59,351 & 7.08 & 5.10 & 1.00 & 22.00 \\
\hline Credit outlook & 59,351 & -0.20 & 0.52 & -1.00 & 1.00 \\
\hline Stock market return & 51,979 & 0.81 & 6.47 & -37.38 & 51.49 \\
\hline VIX index & 60,626 & 20.91 & 8.29 & 11.40 & 46.35 \\
\hline Yield & 51,609 & 5.67 & 4.05 & 0.40 & 65.60 \\
\hline Long-term interest rate & 42,278 & 4.53 & 3.35 & 0.00 & 29.20 \\
\hline Logarithm of the CDS spread & 52,205 & 4.71 & 1.07 & 2.10 & 9.61 \\
\hline Credit rating change in the past 3 months & 59,351 & -0.05 & 0.45 & -6.00 & 6.00 \\
\hline Credit outlook change in the past 3 months & 59,351 & 0.00 & 0.36 & -2.00 & 2.00 \\
\hline \multicolumn{6}{|l|}{ Pension fund characteristics } \\
\hline Lagged logarithm of total holdings & 55,635 & 15.94 & 1.03 & 13.67 & 19.64 \\
\hline Lagged funding ratio & 55,655 & 1.09 & 0.13 & 0.77 & 1.57 \\
\hline Lagged relative returns by sovereign & 55,635 & 0.23 & 5.73 & -45.82 & 36.40 \\
\hline Lagged relative performance fixed-interest investments & 55,611 & 0.73 & 1.28 & -7.26 & 13.37 \\
\hline Lagged distance to the SAA & 55,635 & 0.22 & 0.23 & 0.00 & 3.53 \\
\hline Lagged risk preference & 53,016 & 0.72 & 0.40 & 0.07 & 4.08 \\
\hline Lagged percentage of sovereign holding & 58,093 & 0.05 & 0.11 & 0.00 & 1.00 \\
\hline
\end{tabular}

We disregard indirect investments which may be managed by an external asset manager who works for many pension funds. ${ }^{18}$ Second, holdings of long-term sovereign debt are assumed to be managed more passively than equity or corporate bond investments. Third, in comparison with open-end funds, herding is likely to be lower as the assets of Dutch pension funds cannot be directly redeemed by their participants. This effectively rules out herd behavior by fund investors, which can sometimes be observed for mutual funds (Kaminsky et al., 2004). Fourth, we focus on the LSV herding measure. Bellando (2010) shows that the LSV herding measure underestimates true herding, although this bias decreases with the number of transactions. There are, on average, ten transactions in a country per month. When we impose a minimum number of five trades, there are, on average, fourteen transactions in a country per month. This somewhat limits the underestimation of true herding. Even though, our results are conservative estimates of true herd behavior.

\footnotetext{
${ }^{18}$ Pension fund asset managers may be influenced by their external asset managers (e.g., presentations, roadshows or investment information). This study only uses direct investments by pension funds because our analysis reveals that pension funds with the same external asset manager do not exhibit different herd behaviour than pension funds with different external asset managers. We checked this with data from DNB's pension fund supervision dataset. Annual data is available on asset management firms that manage over $30 \%$ of holdings of a specific pension fund. For our sample, the number of different asset managers is 175 . We identify the pension funds with matching asset managers. These pension funds do not exhibit more intensive herd behaviour than pension funds that use different asset managers. Thus, our findings are not driven by underlying herd behaviour due to similar information from the external asset management firm.
} 


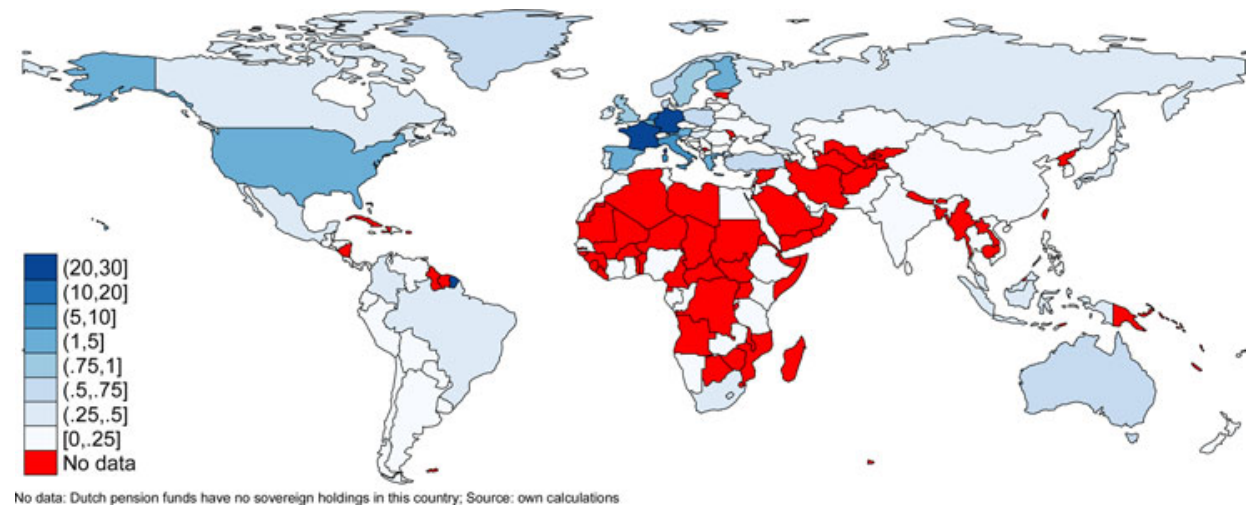

Figure 1. The average percentage of pension fund's sovereign holdings by country between December 2008 and December 2014.

Figure 2. The geographical spread of pension funds' trades between December 2008 and December 2014.

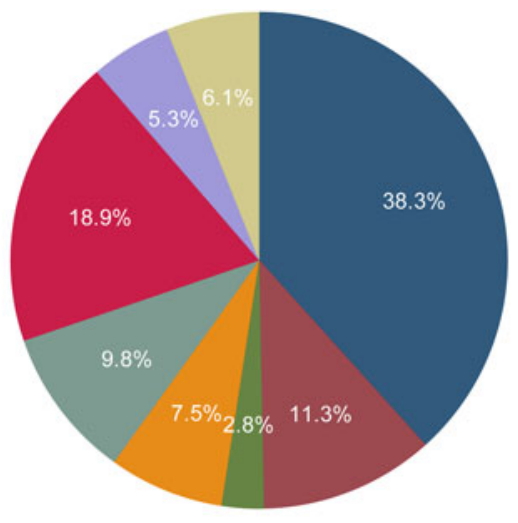

\begin{tabular}{|l|}
\hline Euro area \\
Non-Euro area advanced economies \\
Commonwealth of Independent States \\
Emerging and developing Asia \\
Emerging and developing Europe \\
Latin America and the Caribbean \\
Middle East, North Africa, Afghanistan and Pakistan \\
Sub-Saharan Africa \\
\hline
\end{tabular}

\section{Empirical results}

\subsection{Herd behavior}

\subsubsection{Herd behavior of pension funds}

Herd behavior can only be measured accurately if there is a minimum amount of purchases or sales. In our case, there must be multiple pension funds trading in a long-term sovereign bond of country (i) during month $(t)$. Table 2 shows that the overall, buy and sell herding measures are $0.14,0.12$ and 0.16 for a minimum of three trades, respectively. The number of trades corresponds to the number of unique pension funds buying or selling a particular sovereign within a specific month. For the buy herding, it implies that assuming that the average fraction of increases was $0.5,62 \%$ of the pension funds were changing their holdings of a particular sovereign bond in one direction and $38 \%$ in the 


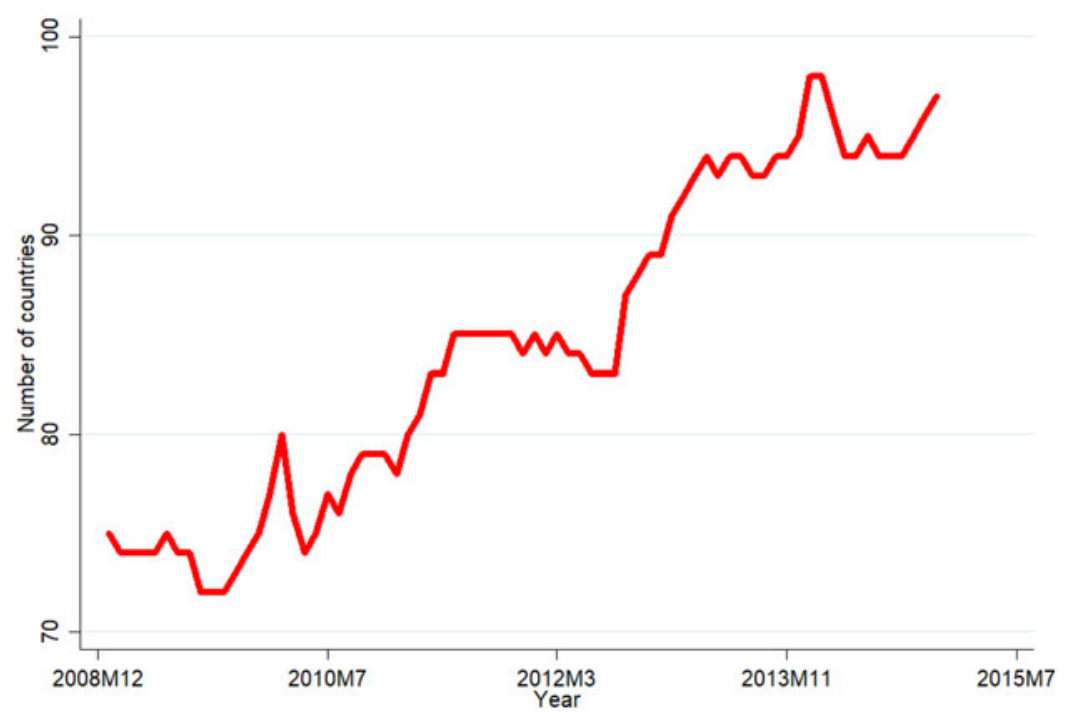

Figure 3. The number of countries in which Dutch pension funds' trade per month.

Table 2. Herding measures and trading intensity

\begin{tabular}{|c|c|c|c|c|c|c|}
\hline & \multicolumn{2}{|c|}{ LSV herding measure } & \multicolumn{2}{|c|}{$\begin{array}{l}\text { LSV herding measure for } \\
\text { position continuing trades }\end{array}$} & \multicolumn{2}{|c|}{ FHW herding measure } \\
\hline & Observations & Mean & Observations & Mean & Observations & Mean \\
\hline \multicolumn{7}{|c|}{ Overall herding measure } \\
\hline Minimal 3 trades & 40,048 & 0.14 & 15,893 & 0.12 & 40,048 & 0.28 \\
\hline Minimal 5 trades & 37,204 & 0.13 & 12,705 & 0.12 & 37,204 & 0.26 \\
\hline Minimal 10 trades & 28,419 & 0.11 & 5,156 & 0.13 & 28,419 & 0.22 \\
\hline Minimal 15 trades & 18,492 & 0.11 & 2,422 & 0.14 & 18,492 & 0.20 \\
\hline \multicolumn{7}{|l|}{ Buy herding measure } \\
\hline Minimal 3 trades & 23,750 & 0.12 & 7,468 & 0.16 & 23,750 & 0.23 \\
\hline Minimal 5 trades & 22,887 & 0.12 & 6,411 & 0.16 & 22,887 & 0.23 \\
\hline Minimal 10 trades & 19,422 & 0.12 & 3,260 & 0.16 & 19,422 & 0.22 \\
\hline Minimal 15 trades & 14,250 & 0.13 & 1,562 & 0.16 & 14,250 & 0.22 \\
\hline \multicolumn{7}{|l|}{ Sell herding measure } \\
\hline Minimal 3 trades & 16,298 & 0.16 & 8,425 & 0.08 & 16,298 & 0.33 \\
\hline Minimal 5 trades & 14,317 & 0.15 & 6,294 & 0.08 & 14,317 & 0.31 \\
\hline Minimal 10 trades & 8,997 & 0.09 & 1,896 & 0.07 & 8,997 & 0.21 \\
\hline Minimal 15 trades & 4,242 & 0.05 & 860 & 0.10 & 4,242 & 0.14 \\
\hline
\end{tabular}

Notes: This table reveals the overall, buy and sell herding measure for the LSV herding measure, the LSV herding measure for position continuing trades and the FHW herding measure. The number of trades corresponds to the number of unique pension funds buying or selling a particular sovereign within a specific month. We impose a minimum of 3, 5, 10 or 15 trades. The number of observations is the total number of trades over the entire sample period for each minimum number of trades criterion. All results are significant at the $1 \%$ level.

opposite direction. In a similar vein, for sell herding, it implies that $66 \%$ of the pension funds were changing their holdings of a particular sovereign bond in one direction and $34 \%$ in the opposite direction. The somewhat stronger sell herding might be explained by risk aversion and liquidity considerations. When multiple pension funds sell off specific sovereign holdings, there can be consequences for liquidity and the pension fund's relative performance, whereas 'staying close to the pack' at least partly mitigates these issues. On average, the herding measure equals 0.14 , whereas the herding measure obtained for equity investments is around 0.03 (Lakonishok et al., 1992; Grinblatt et al., 1995; Jame, 2011). As a robustness check, we estimate the LSV herding measure using the augmented 
Figure 4. The density of the LSV herding measure with a minimum of five trades between December 2008 and December 2014.

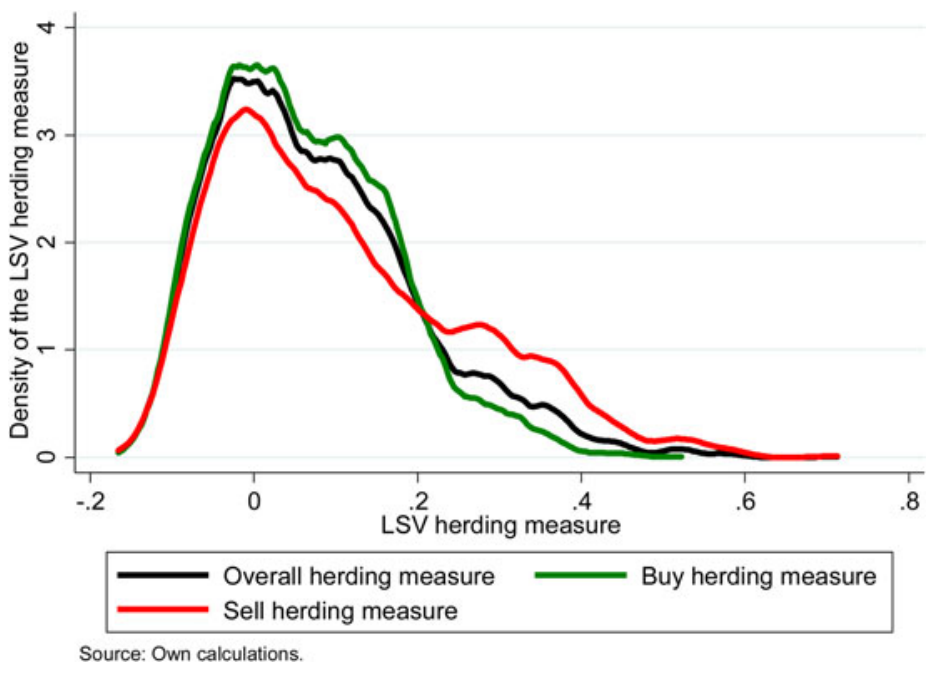

interest rate, ${ }^{19}$ which allows us to include more countries in our analysis. Our findings reveal a somewhat lower intensity of herd behavior.

Although our findings are robust, there is considerable heterogeneity in the underlying distribution. Figure 4 shows three univariate kernel density functions (overall, buy and sell herding) for an LSV herding measure. There is considerable variation in the intensity of pension funds' herd behavior. The figure also reveals that the distribution of sell herding is much more skewed with herding measures of sometimes over 0.4 than the distribution of buy herding measures.

Position continuing trades could play a role in the observed herd behavior (Table 2). Pension funds can potentially follow their own investments (e.g., Sias, 2004). Implementation of an investment decision can take several months, especially if the decision is taken at the end of the month. As a second robustness test, this study accounts for pension funds following their own purchases or sales by disregarding position continuing trades, i.e., it only uses the initial investment decision. The downside of this approach is that useful observations may be disregarded. The herding measures correcting for position continuing trades reveal some different behavior. The buy herding measure is 0.16 two times higher than the sell herding measure (0.08). This contrasts with our earlier findings. A possible explanation is that an illiquid environment renders selling more difficult than buying. Consequently, selling might be a process that takes several months, whereas buy herding is more tied to a specific month. Furthermore, extending the sell-period over multiple months is also relevant in liquid markets as it is expected to reduce the price pressures of a sell-transaction.

The trading intensity can potentially affect the intensity of herding. Figure 5 shows that the number of trades differs considerably per country. We use four restrictions on the number of trades, i.e., 3,5 , 10 or 15 trades per country. Where there is no mentioning of a minimum number of trades, this study uses a minimum of five trades per month in accordance with the herding literature. A higher minimum number of trades gives, of course, a more restricted sample. In general, the overall and sell herding measures decline if the minimum number of trades increases. Sell herding declines from 0.16 with a minimum of 3 trades to 0.05 with a minimum of 15 trades. This could be explained by both unintentional and intentional herding motives. Prompt incorporation of new information and similar interpretation of this information by pension funds can lead to unintentional herding. Pension fund portfolio managers may window dress their portfolios, shedding 'exotic' sovereigns more because large sovereigns are in the portfolios of most portfolio managers, whereas on the buy side, pension funds continue to buy small sovereigns for return considerations.

\footnotetext{
${ }^{19} \mathrm{We}$ adjust the purchases and sell transactions for the accrued interest rate, which is included in these transactions. To maximize the number of countries included, we augment the country-specific interest rates with the continental interest rate. This reduces the number of missing observations.
} 


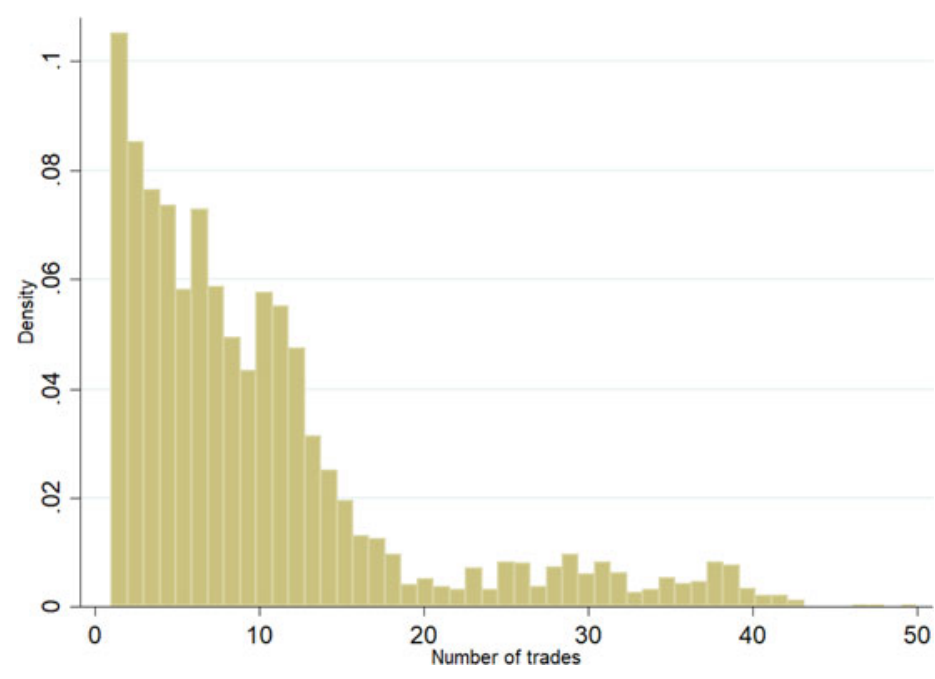

Figure 5. A number of transactions per sovereign bond $i$ in month $t$.

Lakonishok et al. (1992) also find that intentional herding should be more prevalent in small equities, which could also apply to smaller sovereigns. A tentative explanation is that a higher number of trades indicate a more vibrant or larger sovereign debt market. This probably resembles the fact that trading is more frequent in advanced and large economies. There is more (public) information available on these large and vibrant sovereign bond markets. For small sovereigns, portfolio managers are more inclined to infer information from other managers. Scharfstein and Stein (1990) and Rajan (2006) note that underperformance may have an adverse effect on portfolio managers' career prospects. It is more socially acceptable to hold on to, for instance, French sovereign bonds when other asset managers sell these bonds than to hold on to, say, Zambian sovereign bonds.

As a robustness check, we also use the FHW herding measure. This herding measure also shows considerable herd behavior of pension funds in sovereign bonds, confirming our previous findings. As expected, the extent of herding is more pronounced than for the LSV herding measure. The overall herding measure is double (0.28) that of the LSV herding measure (0.14), and this is also roughly the case for buy and sell herding. The FHW herding measures confirm the results of the LSV herding measure as sell herding declines with the number of pension funds trading in a sovereign in a specific month and buy herding is unaffected by the number of trading pension funds. The comparison shows that the results of the LSV herding measure should be interpreted as conservative estimates of true herd behavior.

We conduct additional sensitivity analyses on whether transaction size, the no-short selling constraint and overlapping external asset managers influence our findings. Bikhchandani and Sharma (2000) indicate that the LSV herding measure does not incorporate the size of the transaction. When we use to purchase or sale transactions of EUR 0.5 million or higher, we find slightly higher buy herding (0.11) and slightly lower sell herding (0.13). Another method is to weigh by transaction size so that all transactions are considered. This confirms our earlier findings. Note that our main aim is to investigate herd behavior for which the size of the transaction is less important. However, transaction size does matter when regarding the possible price effects. We also examine the relevance of the no-short selling constraint. Therefore, we only include countries where pension funds already have sovereign holdings (holdings over EUR 1 million or over EUR 5 million), most of our results do not significantly change. ${ }^{20}$ Bauer et al. (2018) show that Dutch pension funds with the same asset

\footnotetext{
${ }^{20}$ The LSV buy herding measure remains 0.12 . For sell herding, we find herding equal to 0.15 with a minimum sovereign holding of EUR 1 million and 0.14 with a minimum sovereign holding of EUR 5 million. This is somewhat surprising as the likelihood of sell herding does not increase with the size of the sovereign holding at the start of the month. This finding shows that the no-short selling constraint does not influence our results.
} 


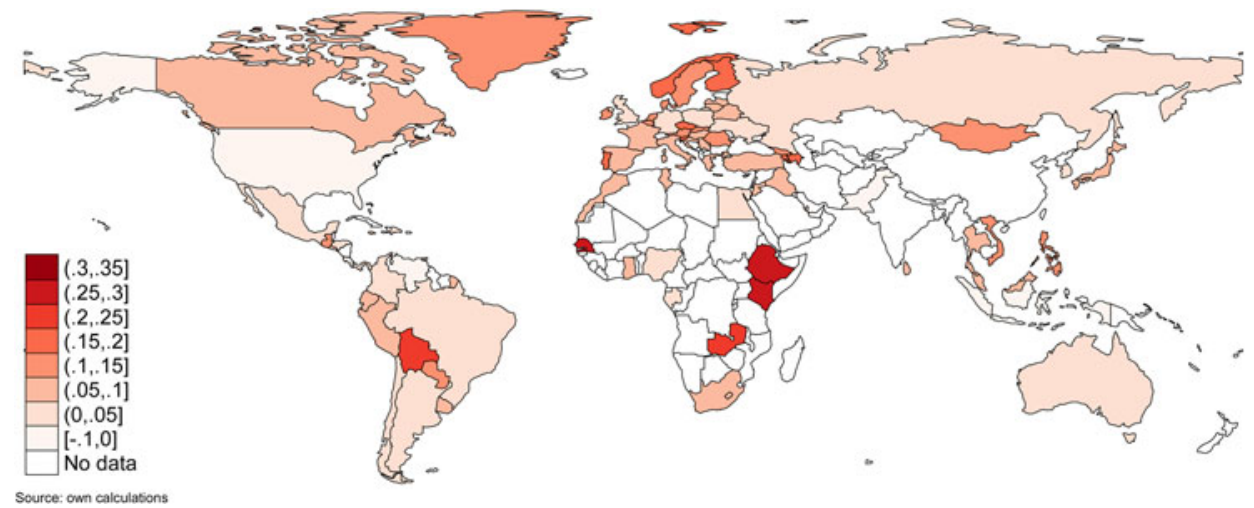

Figure 6. Buy herding measure by country between December 2008 and December 2014.

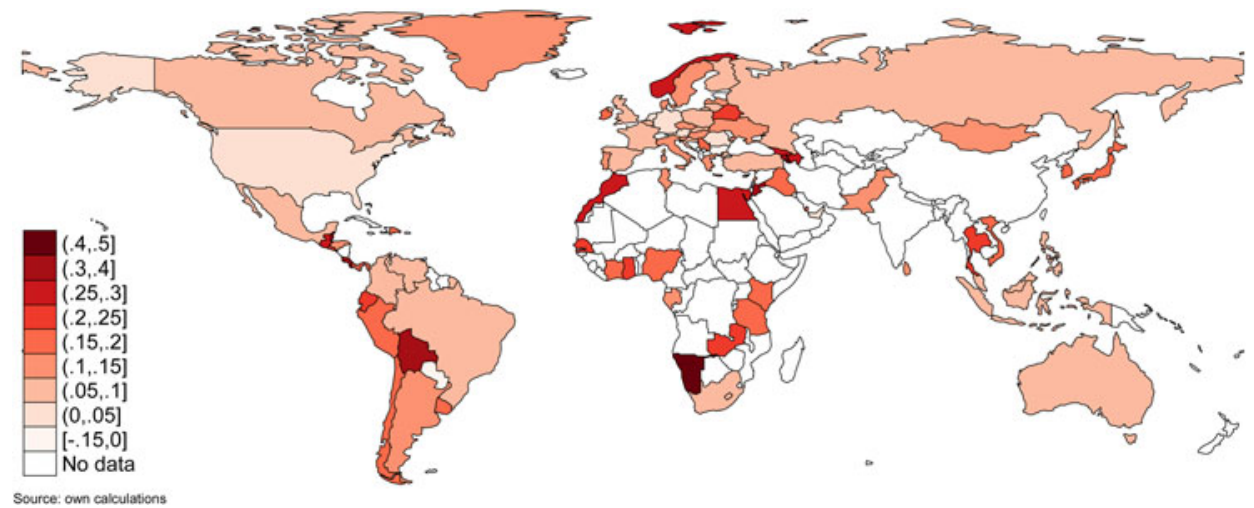

Figure 7. Sell herding measure by country between December 2008 and December 2014.

manager exhibit herd behavior. Therefore, we focus on direct sovereign bond investments by pension funds. However, this still leaves the possibility that pension funds receive similar information or strategies from the same external asset managers. Our findings reveal that the LSV herding measures do, on average, not significantly differ between funds with the same asset managers and those with different asset managers. ${ }^{21}$

\subsubsection{The European debt crisis}

Whether pension funds' herd behavior has aggravated the European debt crisis, is highly debated in policy and academic circles. We start by determining the extent of buy and sell herding in Southern European countries and how this compares to the extent of herding in other countries.

Figures 6 and 7 reveal that the behavior of Dutch pension funds in Southern European does not substantially differ from the behavior we see in other countries. This seems a somewhat surprising finding and probably results from the choice to analyze the entire sample period. Therefore, we examine the extent of herd behavior between safe havens and crisis countries for the non-crisis versus the crisis subperiod. The European debt crisis was at its height from May 2010 to July 2012. The European debt crisis starts with the first bail-out for Greece, whereas it ends with the famous remark from Mario Draghi in July 2012: he would do 'whatever it takes'. Table 3 shows that the safe havens experience substantially higher buy herd behavior ranging from 0.15 to 0.16 than crisis countries (ranging from 0.03 to 0.07 )

\footnotetext{
${ }^{21}$ All results in this section which are not presented are available upon request.
} 
Table 3. The relation between herd behavior and safe havens and crisis countries

\begin{tabular}{|c|c|c|c|c|c|c|c|c|c|c|c|c|}
\hline & \multicolumn{6}{|c|}{ LSV herding measure } & \multicolumn{6}{|c|}{ FHW herding measure } \\
\hline & $\begin{array}{l}\text { Safe } \\
\text { havens } \\
(1)\end{array}$ & $\begin{array}{c}\text { Safe } \\
\text { havens } \\
(2)\end{array}$ & $\begin{array}{c}\text { Safe } \\
\text { havens } \\
\text { (3) }\end{array}$ & $\begin{array}{c}\text { Rescue } \\
\text { package } \\
\text { recipients }\end{array}$ & $\begin{array}{l}\text { Financial aid } \\
\text { recipients }\end{array}$ & $\begin{array}{c}\text { Crisis } \\
\text { countries }\end{array}$ & $\begin{array}{c}\text { Safe } \\
\text { havens } \\
\text { (1) }\end{array}$ & $\begin{array}{l}\text { Safe } \\
\text { havens } \\
(2)\end{array}$ & $\begin{array}{c}\text { Safe } \\
\text { havens } \\
\text { (3) }\end{array}$ & $\begin{array}{l}\text { Rescue } \\
\text { package } \\
\text { recipients }\end{array}$ & $\begin{array}{l}\text { Financial aid } \\
\text { recipients }\end{array}$ & $\begin{array}{c}\text { Crisis } \\
\text { countries }\end{array}$ \\
\hline \multicolumn{13}{|c|}{ Entire sample period, December 2008-December 2014} \\
\hline Overall herding & 0.13 & 0.13 & 0.14 & 0.13 & 0.11 & 0.10 & 0.21 & 0.22 & 0.24 & 0.26 & 0.22 & 0.21 \\
\hline Buy herding & 0.14 & 0.14 & 0.15 & 0.13 & 0.10 & 0.10 & 0.23 & 0.23 & 0.25 & 0.25 & 0.21 & 0.21 \\
\hline Sell herding & 0.03 & 0.04 & 0.06 & 0.13 & 0.11 & 0.09 & 0.09 & 0.10 & 0.15 & 0.27 & 0.24 & 0.21 \\
\hline \multicolumn{13}{|c|}{ European debt crisis, May 2010-July 2012} \\
\hline Overall herding & 0.13 & 0.14 & 0.15 & 0.20 & 0.14 & 0.12 & 0.22 & 0.23 & 0.25 & 0.35 & 0.28 & 0.24 \\
\hline Buy herding & 0.15 & 0.15 & 0.16 & 0.04 & 0.03 & 0.07 & 0.24 & 0.24 & 0.26 & 0.15 & 0.11 & 0.16 \\
\hline Sell herding & 0.02 & 0.03 & 0.06 & 0.24 & 0.18 & 0.15 & 0.06 & 0.09 & 0.16 & 0.38 & 0.32 & 0.28 \\
\hline \multicolumn{13}{|c|}{ Non-crisis period, before May 2010 and after July 2012} \\
\hline Overall herding & 0.12 & 0.12 & 0.13 & 0.11 & 0.10 & 0.09 & 0.21 & 0.21 & 0.23 & 0.22 & 0.20 & 0.19 \\
\hline Buy herding & 0.14 & 0.14 & 0.15 & 0.13 & 0.12 & 0.11 & 0.22 & 0.22 & 0.24 & 0.25 & 0.22 & 0.21 \\
\hline Sell herding & 0.04 & 0.04 & 0.06 & 0.05 & 0.05 & 0.04 & 0.11 & 0.10 & 0.14 & 0.14 & 0.13 & 0.13 \\
\hline Definition & \multicolumn{12}{|c|}{ Countries included } \\
\hline Safe havens (1) & \multicolumn{12}{|c|}{ Finland, Germany, the Netherlands, Switzerland } \\
\hline Safe havens (2) & \multicolumn{12}{|c|}{ Austria, Finland, Germany, the Netherlands, Switzerland } \\
\hline Safe havens (3) & \multicolumn{12}{|c|}{ Austria, Denmark, Finland, Germany, the Netherlands, Norway, Sweden, Switzerland } \\
\hline Rescue package recipients & \multicolumn{12}{|c|}{ Cyprus, Greece, Ireland, Portugal } \\
\hline Financial aid recipients & \multicolumn{12}{|c|}{ Cyprus, Greece, Ireland, Portugal, Spain } \\
\hline Crisis countries & \multicolumn{12}{|c|}{ Cyprus, Greece, Ireland, Italy, Portugal, Spain } \\
\hline
\end{tabular}

Note: This table reveals the overall, buy and sell herding measure for the LSV and FHW herding measure. A distinction is made between safe havens and crisis countries. This study limits the period of the

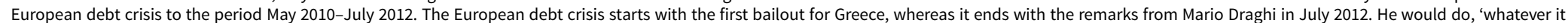
takes'. All results are significant at the $1 \%$ level. 
during the European debt crisis. During this crisis, the difference between safe havens and crisis countries is even more pronounced on the sell side. The LSV sell herding measures for safe havens range from 0.02 to 0.06 . The pension funds exhibit substantially more intensive herd behavior in crisis countries which ranges between 0.15 and 0.24 . For the crisis and non-crisis periods, a similar herding pattern can be observed when we use the FHW herding measure. The herding intensity is, as expected, somewhat more pronounced for the FHW herding measure than for the LSV herding measure.

Remarkably, if we compare safe haven and crisis countries for the non-crisis period, our findings reveal much smaller differences in the LSV herding measure. There is buy and sell herd behavior of a similar magnitude in a safe haven and crisis countries in the non-crisis period. Our findings give some indication that pension funds might have contributed to volatility in the sovereign bond market during the European debt crisis. However, the question remains whether herd behavior was stabilizing or destabilizing. Herding stabilizes bond prices if herding-associated price changes are permanent, while herding destabilizes bond prices if such price changes reverse course (Cai et al., 2019). When new information on the crisis countries comes available, this new information is permanently incorporated in the price of the sovereign bonds. This has a stabilizing effect on the sovereign bond market. However, herd behavior can also simply be the result of mimicking behavior, which is not based on the pension fund's own information. As these herding-associated price changes are not based on information, prices will most likely reverse course because they do not reflect the 'true' value. This has a destabilizing effect on sovereign bond markets.

An open question is whether the European debt crisis has contagion effects on, for example, developing and emerging economies or low-rated sovereigns. We divide our sample into investment and non-investment grade countries ${ }^{22}$; and advanced economies and developing and emerging economies (Table 4). For investment-grade countries, we find buy herding equaling 0.12 and sell herding equaling 0.10 . Sell herding is considerably more intensive for non-investment grade countries $(0.26)$. A relatively similar pattern is observed when we investigate advanced economies and emerging and developing economies. The buy herding measure is 0.13 for advanced economies, and sell herding equal to 0.06. Emerging and developing countries have somewhat lower buy herding (0.08), but most importantly considerable higher sell herding (0.21). As expected, the outcomes of the FHW herding measure give a higher herding intensity than the LSV herding measure.

The buy and sell herding measures for our country groups do not substantially differ between the period of the European debt crisis and the non-crisis period. This gives some indication that the change in the behavior of Dutch pension funds was generally limited to the crisis countries, and that contagion effects to non-investment grade or emerging and developing economies were limited.

\subsubsection{Stabilizing or destabilizing effect?}

The question remains whether herd behavior has a stabilizing or a destabilizing effect on sovereign bond prices. It could potentially be stabilizing, for example, when herding accelerates the incorporation of information on bond prices (Nofsinger and Sias, 1999). We try to establish whether herd behavior has a stabilizing or destabilizing effect by investigating the existence of return reversals. If herd behavior indeed has a stabilizing effect, no return reversals are expected. New information is included in bond prices and will remain included in prices. If the effect is only behavioral, bond prices should reverse in the future. Pension funds will then ignore their own information and trade with the herd. This may move securities away from their price equilibrium and lead to abnormal volatility (Chang et al., 2000). This is the destabilizing effect of herd behavior. There is no consensus in the empirical herding literature on the question of whether herd behavior might be stabilizing or destabilizing. For equity investments, Wermers (1999), Nofsinger and Sias (1999) and Sias (2004) find no evidence of a destabilizing effect, whereas Puckett and Yan (2008) and Dasgupta et al. (2011) do find evidence of such effect. In their study on corporate bonds, Cai et al. (2019) show that destabilizing effects are concentrated on the sell side and in junk bonds.

\footnotetext{
${ }^{22}$ Note that a country's classification can change based on its rating.
} 
Table 4. The relation between herd behavior and country groups

\begin{tabular}{|c|c|c|c|c|c|c|c|c|c|c|}
\hline & \multicolumn{5}{|c|}{ LSV herding measure } & \multicolumn{5}{|c|}{ FHW herding measure } \\
\hline & $\begin{array}{c}\text { All } \\
\text { countries }\end{array}$ & $\begin{array}{l}\text { Investment } \\
\text { grade }\end{array}$ & $\begin{array}{c}\text { Non-investment } \\
\text { grade }\end{array}$ & $\begin{array}{l}\text { Advanced } \\
\text { economies }\end{array}$ & $\begin{array}{c}\text { Emerging and } \\
\text { developing } \\
\text { economies }\end{array}$ & $\begin{array}{c}\text { All } \\
\text { countries }\end{array}$ & $\begin{array}{l}\text { Investment } \\
\text { grade }\end{array}$ & $\begin{array}{c}\text { Non-investment } \\
\text { grade }\end{array}$ & $\begin{array}{l}\text { Advanced } \\
\text { economies }\end{array}$ & $\begin{array}{c}\text { Emerging and } \\
\text { developing } \\
\text { economies }\end{array}$ \\
\hline \multicolumn{11}{|c|}{ Entire sample period, December 2008-December 2014} \\
\hline Overall herding & 0.13 & 0.12 & 0.22 & 0.12 & 0.16 & 0.26 & 0.23 & 0.39 & 0.22 & 0.32 \\
\hline Buy herding & 0.12 & 0.12 & 0.11 & 0.13 & 0.08 & 0.23 & 0.23 & 0.25 & 0.24 & 0.20 \\
\hline Sell herding & 0.15 & 0.10 & 0.26 & 0.06 & 0.21 & 0.31 & 0.24 & 0.43 & 0.17 & 0.37 \\
\hline \multicolumn{11}{|c|}{ European debt crisis, May 2010-July 2012} \\
\hline Overall herding & 0.13 & 0.12 & 0.22 & 0.12 & 0.16 & 0.27 & 0.24 & 0.39 & 0.24 & 0.32 \\
\hline Buy herding & 0.12 & 0.12 & 0.13 & 0.14 & 0.07 & 0.24 & 0.24 & 0.28 & 0.25 & 0.20 \\
\hline Sell herding & 0.15 & 0.11 & 0.25 & 0.09 & 0.20 & 0.31 & 0.25 & 0.41 & 0.21 & 0.36 \\
\hline \multicolumn{11}{|c|}{ Non-crisis period, before May 2010 and after July 2012} \\
\hline Overall herding & 0.13 & 0.11 & 0.22 & 0.11 & 0.16 & 0.26 & 0.23 & 0.39 & 0.22 & 0.33 \\
\hline Buy herding & 0.12 & 0.12 & 0.11 & 0.13 & 0.08 & 0.23 & 0.23 & 0.23 & 0.23 & 0.19 \\
\hline Sell herding & 0.14 & 0.10 & 0.26 & 0.05 & 0.21 & 0.31 & 0.24 & 0.43 & 0.15 & 0.38 \\
\hline
\end{tabular}

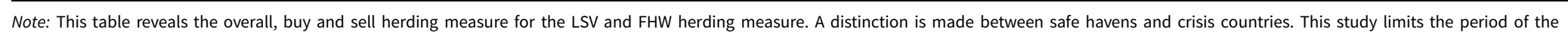

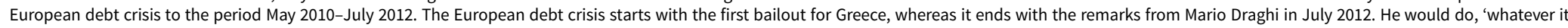
takes'. All results are significant at the $1 \%$ level. 
We focus on the overall returns extracted from DNB's balance of payments database. ${ }^{23,24}$ Following the standard practice in the financial literature, we also estimate the return reversals for winsorized returns. Our investigation includes the time of the European debt crisis. This may cause very volatile asset returns, especially in long-term government bonds. Potential extreme returns can influence our results on the stabilizing or destabilizing effect of herd behavior. To control for this, the returns are winsorized. ${ }^{25}$ We present the results for the returns, which are winsorized at the 0.1 th and 99.9th percentile. This deals with the extreme returns, but preserves most of the observations. Furthermore, we assume that the within-month investments are equally spread over 20 workdays.

We follow the procedure as described by Wermers (1999) to identify return reversals. For each month, we use all sovereign bonds that are traded by at least five pension funds and divide them between buy and sell herding in accordance with equations (5) and (6). This results in ten portfolios, five for buys and five for sells. The quintile which exhibits the strongest and the weakest buy herding are classified as $B 5$ and $B 1$, respectively. A similar procedure is followed to sell herding. The monthly abnormal return is calculated as the monthly buy-and-hold return of sovereign bonds formed in the formation month minus the buy-and-hold return control portfolio. In other words, to calculate these portfolio returns for a given month, we subtract, from the monthly buy-and-hold return of each sovereign bond in the portfolio, the monthly buy-and-hold return of the portfolio of all sovereign funds belonging to the same quintile as the sovereign bond at the beginning of the month. We investigate the abnormal return from two months prior to the transaction until five months after the transaction. In this way, we can see whether a return reversal occurs. Note that if the distance between the month of purchase or sell transaction and return reversal increases, the connection between the transaction and the reversal is somewhat less strong. However, we have monthly data whereas most studies, such as Wermers (1999), use quarterly data. Therefore, the connection between the transaction and return reversal in our analysis is stronger as it is closer to the purchase or sell transaction than in most herding studies.

Our findings reveal some mixed evidence on stabilizing and destabilizing behavior (see Table 5). The returns reversals for sell herd behavior are statistically significant, whereas the results for buy herd behavior indicate that return reversals do not always occur. There are immediate return reversals for two sell quintiles, $S 4, S 3$ and $S 1$. This indicates the clear destabilizing behavior of pension funds. When analyzing the return reversals using only price returns as a robustness check, our results also reveal mixed evidence on stabilizing behavior.

Country characteristics lead to the different behavior of pension funds (see Table 6). The most notable may be the difference in behavior when controlling for sovereign ratings. Based on their ratings, we divide the countries into two groups: investment and non-investment grade. For investment-grade countries, we find some evidence of destabilizing behavior in sell herding, except for $S 4$. However, we find evidence of mostly stabilizing behavior on the buy side, except for B2. Our results for noninvestment grade countries show mixed evidence on stabilizing behavior. On the buy and sell side, we find evidence of return reversals for roughly half of the quintiles, which means that there is evidence that trading by Dutch pension funds is sometimes destabilizing in non-investment grade countries. Somewhat surprisingly, this finding also holds for advanced economies, although most return reversals on the sell side occur relatively late: 5 months after the sell transaction. This makes the link between the transaction itself and destabilization somewhat weaker in comparison to instantaneous return reversals. For emerging and developing economies, we find destabilizing behavior on the sell side (except for S4), whereas, on the buy side, there is mixed evidence of stabilization. Overall, the

\footnotetext{
${ }^{23} \mathrm{We}$ also estimate existence of return reversals using price returns. These results are available upon request.

${ }^{24}$ Our data does not include the exact transaction dates during the month, so the exact returns are difficult to calculate on a monthly basis. These returns depend to a certain extent on the dates of purchases and sales. We assume that there are 20 trading days in a month. Investments are made in equal daily amounts. When we take different purchase and sales dates within the month, the results are highly similar.

${ }^{25}$ The results are obtained for winsorizing at 0.1 th and 99.9 th percentile, at 0.5 th and 99.5 th percentile and at 1 st and 99th percentile.
} 
Table 5. Total return reversals per quintile

\begin{tabular}{ccccccccc}
\hline Quintile & $a r_{t-2}$ & $a r_{t-1}$ & $a r$ & $a r_{t+1}$ & $a r_{t+2}$ & $a r_{t+3}$ & $a r_{t+4}$ & $a r_{t+5}$ \\
\hline Sell herding & & & & & & & & \\
S5 & 0.067 & 0.520 & 1.224 & 0.479 & 0.648 & -0.191 & -0.602 & -0.364 \\
& $(0.335)$ & $(2.646)$ & $(4.672)$ & $(1.998)$ & $(3.088)$ & $(-0.921)$ & $(-2.565)$ & $(-1.359)$ \\
S4 & -0.289 & 1.033 & -0.235 & 0.638 & -0.218 & 0.333 & -0.067 & 0.506 \\
& $(-1.532)$ & $(4.612)$ & $(-1.363)$ & $(3.009)$ & $(-1.111)$ & $(1.494)$ & $(-0.333)$ & $(2.609)$ \\
S3 & 0.122 & -0.520 & 0.434 & -0.458 & 0.301 & -0.134 & 0.885 & -0.016 \\
& $(0.713)$ & $(-2.885)$ & $(1.861)$ & $(-3.035)$ & $(1.315)$ & $(-0.999)$ & $(3.484)$ & $(-0.143)$ \\
S2 & 0.093 & 0.204 & -0.299 & -0.424 & 0.240 & -0.282 & -0.158 & 0.505 \\
& $(0.710)$ & $(0.964)$ & $(-2.099)$ & $(-2.820)$ & $(1.217)$ & $(-2.497)$ & $(-0.795)$ & $(2.525)$ \\
S1 & -0.119 & 0.343 & 0.243 & -0.392 & -0.309 & -0.263 & 0.163 & -0.319 \\
& $(-2.625)$ & $(2.146)$ & $(1.762)$ & $(-2.992)$ & $(-2.296)$ & $(-2.667)$ & $(1.082)$ & $(-2.625)$ \\
Buy herding & & & & & & & & \\
B5 & -0.309 & 0.183 & -0.091 & 0.116 & -0.173 & 0.099 & -0.255 & -0.117 \\
& $(-2.722)$ & $(1.221)$ & $(-0.930)$ & $(0.895)$ & $(-1.526)$ & $(1.079)$ & $(-3.336)$ & $(-0.955)$ \\
B4 & -0.136 & 0.010 & 0.050 & -0.239 & -0.112 & 0.029 & -0.078 & -0.174 \\
& $(-1.324)$ & $(0.102)$ & $(0.436)$ & $(-2.479)$ & $(-1.554)$ & $(0.318)$ & $(-0.902)$ & $(-1.947)$ \\
B3 & 0.049 & -0.226 & -0.064 & -0.080 & -0.391 & -0.142 & -0.267 & -0.025 \\
& $(0.468)$ & $(-1.904)$ & $(-0.485)$ & $(-0.740)$ & $(-4.078)$ & $(-1.141)$ & $(-2.756)$ & $(-0.221)$ \\
B2 & -0.087 & -0.177 & 0.174 & 0.021 & 0.171 & -0.192 & 0.017 & 0.018 \\
& $(-0.681)$ & $(-2.603)$ & $(1.440)$ & $(0.208)$ & $(2.589)$ & $(-3.599)$ & $(0.241)$ & $(0.248)$ \\
B1 & 0.213 & -0.178 & 0.014 & 0.091 & -0.035 & 0.089 & -0.353 & -0.086 \\
& $(1.428)$ & $(-1.390)$ & $(0.094)$ & $(0.796)$ & $(-0.282)$ & $(0.647)$ & $(-3.967)$ & $(-0.606)$ \\
\hline
\end{tabular}

Note: This table reveals whether return reversals are present. We follow the procedure as described by Wermers (1999) to identify return reversals. For each month, we use all sovereign bonds that are traded by at least five pension funds and divide them between buy and sell herding in accordance with equations (5) and (6). This results in ten portfolios, five for buys and five for sells. The quintile which exhibits the strongest and the weakest buy herding are classified as $B 5$ and $B 1$, respectively. A similar procedure is followed to sell herding. The monthly abnormal return is calculated as the monthly buy-and-hold return of sovereign bonds formed in the formation month minus the buy-and-hold return control portfolio. The return consists of price changes and exchange rate changes. This calculation gives the ar which is the abnormal return. The table shows whether the abnormal return is significantly different from zero for the two months prior to the buy or sell month $\left(a r_{t-2}\right.$ and $\left.a r_{t-1}\right)$, and for the five months after the buy or sell month $\left(a r_{t+1}, \ldots, a r_{t+5}\right)$. The $t$ statistics are in parentheses.

Table 6. Overview of total return reversals per quintile

\begin{tabular}{|c|c|c|c|c|c|c|c|}
\hline Quintile & $\begin{array}{c}\text { All } \\
\text { countries }\end{array}$ & $\begin{array}{l}\text { Investment } \\
\text { grade bonds }\end{array}$ & $\begin{array}{l}\text { Noninvestment } \\
\text { grade bonds }\end{array}$ & $\begin{array}{l}\text { Advanced } \\
\text { economies }\end{array}$ & $\begin{array}{c}\text { Emerging and } \\
\text { developing } \\
\text { economies }\end{array}$ & $\begin{array}{c}\text { Crisis } \\
\text { countries }^{a}\end{array}$ & Safe havens \\
\hline \multicolumn{8}{|c|}{ Sell herding } \\
\hline S5 & $t+4$ & $t+4$ & $t+3$ & Insignificant & $t+4$ & Insignificant & $t+3$ \\
\hline S4 & $t+1$ & Insignificant & $t+1$ & Insignificant & Insignificant & Insignificant & $t+2$ \\
\hline S3 & $t+1$ & $t+4$ & Insignificant & $t+5$ & $t+3$ & Insignificant & Insignificant \\
\hline $\mathrm{S} 2$ & $t+5$ & $t+5$ & Insignificant & $t+5$ & $t+2$ & Insignificant & $t+1$ \\
\hline $\mathrm{S} 1$ & $t+1$ & $t+1$ & $t+3$ & $t+1$ & $t+1$ & $t+1$ & Insignificant \\
\hline \multicolumn{8}{|c|}{ Buy herding } \\
\hline B5 & Insignificant & Insignificant & $t+1$ & Insignificant & $t+1$ & $x$ & $t+5$ \\
\hline B4 & $t+1$ & Insignificant & Insignificant & $t+1$ & $t+2$ & $x$ & Insignificant \\
\hline B3 & Insignificant & Insignificant & Insignificant & $t+2$ & Insignificant & $x$ & $t+3$ \\
\hline B2 & $t+3$ & $t+3$ & $t+2$ & $t+3$ & $t+2$ & $x$ & Insignificant \\
\hline $\mathrm{B} 1$ & $t+4$ & Insignificant & Insignificant & Insignificant & Insignificant & $x$ & $t+1$ \\
\hline
\end{tabular}

${ }^{a}$ During the European debt crisis, there are no buy herds for crisis countries.

Note: This table reveals whether return reversals are present. We follow the procedure are described by Wermers (1999) to identify return reversals. For each month, we use all sovereign bonds that are traded by at least five pension funds and divide them between buy and sell herding in accordance with equations (5) and (6). This results in ten portfolios, five for buys and five for sells. The quintile which exhibits the strongest and the weakest buy herding are classified as $B 5$ and $B 1$, respectively. A similar procedure is followed to sell herding. The monthly abnormal return is calculated as the monthly buy-and-hold return of sovereign bonds formed in the formation month minus the buy-and-hold return control portfolio. The return consists of price changes and exchange rate changes. Insignificant means that there are no significant return reversals in the five months after the purchase or sale transaction. When there is a significant return reversal, this is indicated by showing the month in which this significant reversal takes place. 
findings on a stabilizing effect of Dutch pension funds trading are rather mixed, where the stabilizing effect is more likely to occur on the buy side.

We also investigate the stabilizing or destabilizing effect of Dutch pension funds' trading during the European debt crisis. Our findings reveal that this crisis in the Southern European countries and Ireland is most likely not deepened by the behavior of Dutch pension funds. We find no evidence of return reversals, and thus destabilizing behavior (except for the least intensive sell quintile, S1). In contrast, we do find some evidence of destabilizing behavior by Dutch pension funds' trading behavior in safe-haven countries. This finding is relatively similar to our earlier findings.

Our mixed results can probably be attributed to the market circumstances, more particularly the existence of extreme returns. We use winsorized and non-winsorized returns to estimate stabilizing or destabilizing behavior. ${ }^{26}$ We find that extreme market circumstances in the sovereign bond market increase the likelihood of finding a stabilizing effect. In other words, if more extreme returns are winsorized, we do find more return reversals. One explanation for this may be that pension funds engage in more aggressive rebalancing behavior for these quintiles. If no adjustments are made when extreme returns materialize during intensive herding, the pension fund's strategic asset allocation will be unattainable, even if there is a bandwidth around this allocation. Pension funds' internal rules make them rebalance their portfolio back to their strategic asset allocation. From a social welfare perspective, they contribute at the time when the financial markets are volatile (extreme high or extreme low returns), whereas in normal market circumstances pension funds may occasionally deviate from their strategic asset allocation because of market timing.

We perform numerous robustness checks. First, we use the portfolio approaches of Cai et al. (2019) to establish return reversals. We find also mixed results at the portfolio level. Second, we use the country-specific interest rates augmented by the continental interest rate to maximize the number of countries included. This does not alter our main findings. Third, we also obtain return data from sovereign market indices. ${ }^{27}$ Overall, we find somewhat stronger evidence of returns reversals and thus destabilizing behavior. Fourth, this study uses different investment moments within the month. This accounts for the possibility that differences in returns are driven by the timing of the investment. We investigate investments at the beginning, at the end, at the middle, at the middle and the end, and at the end of every week (four equal amounts) and at payday in the Netherlands (the 25th of every month). These alternatives have not changed our main findings, meaning that our findings are not driven by the timing of the investment moment within the month. Although we find some evidence of a destabilizing effect of pension funds in normal market circumstances, it is important to note that prices can move away from their fundamental values for some other reasons, like inventory costs considerations or market frictions. ${ }^{28}$

\subsection{Determinants of herd behavior}

\subsubsection{Quintile analysis}

We further investigate what determines the extent of herding by Dutch pension funds. We start with using quintile analysis to investigate whether pension fund characteristics, financial market sentiment and macroeconomic circumstances play a role in the extent of herding. The values of all pension fund, financial market and macroeconomic variables are ordered from low to high and divided into five

\footnotetext{
${ }^{26}$ These results are available upon request.

${ }^{27}$ We use the non-hedged sovereign bond indices denominated in euros. Thus, our study also includes the returns from the exchange rate changes.

${ }^{28}$ Our results should be interpreted with care as not all deviations are caused by non-informational reasons. Cai et al (2019) identify three reasons: (1) Dealers' inventory costs; (2) the regulatory regime and (3) downward sloping demand curves. (1) Pension funds mainly trade in highly liquid frequently traded securities, which have a limited bid-ask spread. Normally, this is the case for (frequently traded) sovereign bonds. (2) The Dutch regulatory regime is relatively mild. Pension funds are not directed (actively) into specific sovereign bonds. (3) In neo-classical theory, prices equal expected future discounted cash flows, as a consequence demand curve would normally be horizontal.
} 
equally sized groups called quintiles. The ordering exercise is repeated every month. We present the herding measure for the quintiles with the lowest (1) and highest (5) values for each variable. For example, we present the LSV herding measure for the lowest and highest economic growth quintile and investigate whether there is a significant difference between the intensity of herd behavior.

Macroeconomic circumstances seem to be driving both buy and sell herd behavior, although there is considerable heterogeneity in terms of intensity in buy and sell herding (the top part of Table 7). Low inflation increases buy herd behavior, whereas sell herd behavior hardly differs from inflation. Pension fund managers typically invest in countries with low inflation as it is a sign of a stable macroeconomic environment. A current account deficit promotes sell herding strongly, while sell herding decreases substantially when there is a current account surplus. Pension funds' managers may prefer countries with a current account surplus as it indicates that the county's economy is competitive and gives an indication of the ability to pay foreign currency denominated sovereign bonds. Low exchange rate volatility fosters buy herd behavior, whereas sell herding increases with the exchange rate volatility. Lower exchange rate volatility drives fluctuations in the euro value of assets down or decreases the costs of a currency hedge. GDP growth also affects both buy and sell herding. Low growth rates stimulate buy herding and lower sell herding. Low growth rates seem to indicate a stable macroeconomics environment.

Low general government debt leads to high sell herding. When we consider the size of the sovereign bonds' market, herding is much more intensive for small sovereign bond markets on the buy and sell side. Pension fund managers seem more likely to hold on to sovereigns of large bond markets, in a similar fashion as in large shares. High net government lending aggravates both buy and sell herding. Our findings reveal a similar pattern for institutional indicators. These indicators show high buy herding for countries with a good institutional environment. There is high sell herding for sovereigns of countries with a weak institutional setting. Low unemployment somewhat increases buy herding, but also shows somewhat higher sell herding.

The institutional variables reveal a similar pattern across all variables. This pattern is driven by the high correlations between institutional variables, ${ }^{29}$ so our results should be interpreted with great care. The overall pattern shows high buy herd behavior, when the quality of institutions is high, whereas sell herding is extremely high for countries that have poor institutions.

The financial market sentiment is also impacting herding intensity (the middle panel of Table 7). There seems to be no shift towards sovereign bonds when the stock market performance is poor, or vice versa. Low bond yields increase buy herding, while sell herding intensifies to 0.24 for countries with the highest yields. A similar pattern is observed for the CDS spread. It seems that pension funds shy away from high risk-high return investments. A high credit rating (a low score) results in more intensity buy herding, and the other way around for sell herding. ${ }^{30}$ These effects indicate that the investment decisions made by Dutch pension funds do not seem to be primarily driven by returns. Higher yields are compensation for higher risks (e.g., a less stable macroeconomic or political environment) and pension funds seem to be unwilling to take these (additional) risks, in accordance with earlier findings (Bikker et al., 2010; De Haan and Kakes, 2011).

Pension fund characteristics are less important for herd behavior than macroeconomic circumstances and financial market sentiment (the bottom panel of Table 7). Large pension funds herd more intensively on the sell side than small pension funds. On the sell side, a larger distance to the strategic asset allocation leads to less sell herding. There is no room for tactical adjustment of the sovereign holdings when the distance to the strategic asset allocation is large. Our findings reveal

\footnotetext{
${ }^{29}$ The correlation matrix is provided in an earlier version of this paper, Koetsier and Bikker (2017)

${ }^{30}$ Sovereign bond ratings are taken to include numerous aspects of the macroeconomic environment, like GDP per capita, GDP growth, inflation, external debt, level of economic development, default history, unemployment rate, the investment-to-GDP ratio, foreign reserves, current account balance, exports, terms of trade, fiscal policy and political risk (Afonso et al., 2011). The sovereign debt rating is numerically transformed by defining AAA as 1 , AA as 2, etcetera, and $\mathrm{D}$ as 22 .
} 
Table 7. Quintile analysis

\begin{tabular}{|c|c|c|c|c|}
\hline \multirow[b]{2}{*}{ Indicators } & \multicolumn{2}{|c|}{ Buy herding } & \multicolumn{2}{|c|}{ Sell herding } \\
\hline & Quintile 1 & Quintile 5 & Quintile 1 & Quintile 5 \\
\hline \multicolumn{5}{|l|}{ Macroeconomic circumstances } \\
\hline Inflation & 0.14 & 0.07 & 0.20 & 0.18 \\
\hline Current account & 0.10 & 0.13 & 0.23 & 0.09 \\
\hline Exchange rate, change & 0.13 & 0.09 & 0.13 & 0.18 \\
\hline GDP growth & 0.15 & 0.10 & 0.15 & 0.22 \\
\hline General government debt & 0.11 & 0.10 & 0.19 & 0.07 \\
\hline Logarithm of the sovereign bond market size & 0.16 & 0.08 & 0.19 & 0.04 \\
\hline Net government lending & 0.07 & 0.15 & 0.13 & 0.18 \\
\hline Unemployment rate & 0.14 & 0.11 & 0.17 & 0.15 \\
\hline Control of corruption & 0.07 & 0.16 & 0.20 & 0.06 \\
\hline Government effectiveness & 0.08 & 0.17 & 0.24 & 0.06 \\
\hline Political stability and absence of violence/terrorism & 0.08 & 0.17 & 0.18 & 0.10 \\
\hline Regulatory quality & 0.09 & 0.16 & 0.22 & 0.06 \\
\hline Rule of law & 0.07 & 0.17 & 0.22 & 0.06 \\
\hline Voice and accountability & 0.09 & 0.17 & 0.20 & 0.06 \\
\hline \multicolumn{5}{|l|}{ Financial market sentiment } \\
\hline Stock market return & 0.13 & 0.12 & 0.14 & 0.14 \\
\hline Government bond yield & 0.14 & 0.08 & 0.05 & 0.24 \\
\hline Logarithm of the CDS spread & 0.14 & 0.08 & 0.05 & 0.23 \\
\hline Government bond credit rating & 0.14 & 0.10 & 0.04 & 0.26 \\
\hline \multicolumn{5}{|l|}{ Pension fund characteristics } \\
\hline Logarithm of total holdings & 0.12 & 0.11 & 0.12 & 0.17 \\
\hline Funding ratio & 0.12 & 0.12 & 0.16 & 0.15 \\
\hline Relative returns by sovereign & 0.11 & 0.11 & 0.15 & 0.17 \\
\hline Relative performance fixed-interest investments & 0.13 & 0.12 & 0.13 & 0.13 \\
\hline Distance to the $S A A^{a}$ & 0.12 & 0.13 & 0.16 & 0.13 \\
\hline Risk preference & 0.12 & 0.12 & 0.14 & 0.15 \\
\hline Percentage of sovereign holding ${ }^{b}$ & 0.11 & 0.11 & 0.21 & 0.04 \\
\hline
\end{tabular}

Note: We form quintiles for the indicators. The indicators are ordered from low to high and divided into five approximately equal groups, so-called quintiles. We obtain the herding measure for each of these groups. In the table, we use the lowest (1) and highest (5) quintile for each indicator and present the intensity of herding in this particular quintile. The quintiles are constructed on a monthly basis. This means that the divisions are conducted every month. Thus, the position within a quintile is fixed within a month, but it can differ between months. The quintile analysis is conducted with a minimum of five trades. The quintiles 1 and 5 are presented for both buy and sell herding. We exclude categorical variables and indicators with no monthly variation. All results are significant at the $1 \%$-level.

${ }^{a}$ Absolute distance to the strategic asset allocation.

bSovereign holdings in a country as a percentage of the pension fund's total sovereign holdings.

evidence that there is an information advantage if pension funds hold a sizeable share of their sovereign portfolios in a specific country. Sell herding declines from 0.21 for the countries that account for a small proportion of the sovereign portfolio to 0.04 for countries that account for a large proportion of the sovereign portfolio. This can be explained by the different incentives for information collection. Small sovereign bond holdings are relatively costly if there are fixed costs for country-specific investments as noted by Calvo and Mendoza (2000). Consequently, for small investments pension funds may rely more on the information they infer from trades made by other funds and minimize the chance of potential underperformances. This effect is absent on the buy side. ${ }^{31}$ A possible explanation is that for a buy transaction the information on the sovereign holding is collected and reviewed (which can take some time). At that moment of purchase, the pension fund decides based on their own information. The other pension fund characteristics, such as the funding ratio, the pension fund's risk preference and the performance of the pension fund's fixed-interest investments and sovereign bonds, have no effect on sell and buy herding.

\footnotetext{
${ }^{31}$ As a robustness check, we also construct quintiles over the entire sample period. Redefining the quintiles on a monthly basis can lead to differences in the quintile cut-offs between the months, which can potentially influence our results. However, the previous estimations are quite robust.
} 
This section reveals that herding is strongly connected to macroeconomic conditions and financial market sentiment and - to a lesser degree - to pension fund characteristics. In general, sell herding increases with bad economic conditions, more risk and smaller government bond markets, while the opposite is true for buy herding. These relationships make sense and show that our herding measures reflect economically driven behavior rather than arbitrary values.

\subsubsection{Regression analysis}

We observed that pension funds' herd behavior differs considerably with financial market conditions, macroeconomic environment and to a lesser degree of pension fund characteristics. However, the quintile analysis does not account for the relationships between these determinants. In particular, institutional variables are highly correlated amongst each other and with the sovereign rating. There is also a high correlation between the variables sovereign rating, CDS spread and yield. Due to our relatively large sample, statistical significance is insufficient to conclude that an indicator contributes to herd behavior (e.g., Granger, 1998). We also need to check the economic significance of the identified relationship.

We prefer LSDV estimation over other methods because of the low bias and theoretical reasons. ${ }^{32}$ The OLS results are included as they allow us to identify the cross-sectional differences though these estimates may be biased, since herding may depend on unobserved country-pension fund and timefixed effects. We will mainly comment on the results of our preferred LSDV model. Our panel exists of herding data based on five trades or more, as is common practice in the herding literature.

Table 8 shows the effect of pension fund's characteristics, macroeconomic and financial circumstances on overall herding (columns 1-2), buy herding (columns 3-4) and sell herding (columns 5-6). We already excluded the variables which are statistically insignificant or highly correlated with other explanatory variables from our results. ${ }^{33}$ Inflation seems to lower herding. The effect is statistically significant for overall and buy herding in the OLS regression. A current account surplus reduces overall and sell herding in the OLS regression, which may be explained by the fact that the current account serves as an indicator for the competitiveness of a country's economy. Furthermore, a current account surplus makes it easier to serve debt payments, especially if a country holds debt denominated in foreign currencies. Cassimon et al. (2007) note that this is particularly relevant for many developing countries as they rely on foreign capital to finance their budgetary needs.

General government debt substantially lowers overall and buy herding. A possible explanation is that there is a sizable pool of sovereign bonds, which are traded in the secondary market, reducing the possibility of herding to occur. In contrast, high net lending increases overall, buy and sell herding. This might reflect the perceived higher probability of default as a consequence of a higher deficit, which makes investors more prone to herd. Melecky and Raddatz (2015) contend that there are two opposing effects. Although countries have a higher probability of default if they have higher government debt and higher deficits, they often have better financial market access. Institutional factors influence the investment behavior of pension funds. We find a positive effect on buy herding when a country is more stable politically, and no effect on overall or sell herding.

There is a debate in the literature on how sovereign ratings affect the behavior of sovereign bond investors. We find evidence that a lower sovereign rating by S\&P increases overall, buy and sell herding. These results are also economically significant. For example, an increase (lower sovereign rating by $\mathrm{S} \& \mathrm{P}$ ) of one standard deviation increases buy herding by about 0.06 . Thus, pension funds' herding intensifies substantially when countries have a lower sovereign rating by $\mathrm{S} \& \mathrm{P}$, and this holds for buy as well as sell herding.

We adapt the pension fund variables by taking the average at the country level. Following Bikker et al. (2007), the pension fund characteristics are lagged to mitigate possible endogeneity problems. The size of

\footnotetext{
${ }^{32} \mathrm{FD}$ regressions are also conducted because these estimates have the lowest bias according to the econometric literature. However, for the purpose of our study, it is necessary to include level effects, such as the size of the government bond market, and not only the changes. Therefore, we present the LSDV as they allow us to identify the level-effects.

${ }^{33}$ The results for the other specifications are available upon request.
} 
Table 8. Regression results

\begin{tabular}{|c|c|c|c|c|c|c|}
\hline & \multicolumn{2}{|c|}{ Overall herding } & \multicolumn{2}{|c|}{ Buy herding } & \multicolumn{2}{|c|}{ Sell herding } \\
\hline & $\begin{array}{l}\text { OLS } \\
(1)\end{array}$ & $\begin{array}{l}\text { LSDV } \\
(2)\end{array}$ & $\begin{array}{l}\text { OLS } \\
\text { (3) }\end{array}$ & $\begin{array}{l}\text { LSDV } \\
\text { (4) }\end{array}$ & $\begin{array}{l}\text { OLS } \\
(5)\end{array}$ & $\begin{array}{l}\text { LSDV } \\
(6)\end{array}$ \\
\hline Inflation & $\begin{array}{l}-0.79^{\star *} \\
(-2.04)\end{array}$ & $\begin{array}{l}-0.00 \\
(-0.01)\end{array}$ & $\begin{array}{c}-0.98^{\star \star *} \\
(-3.68)\end{array}$ & $\begin{array}{l}-0.07 \\
(-0.16)\end{array}$ & $\begin{array}{c}-0.59 \\
(-1.27)\end{array}$ & $\begin{array}{l}-0.10 \\
(-0.38)\end{array}$ \\
\hline Current account & $\begin{array}{c}-0.45^{\star \star \star} \\
(-2.92)\end{array}$ & $\begin{array}{l}-0.20 \\
(-1.31)\end{array}$ & $\begin{array}{l}-0.10 \\
(-0.69)\end{array}$ & $\begin{array}{l}-0.21 \\
(-0.98)\end{array}$ & $\begin{array}{l}-0.48^{\star \star} \\
(-2.40)\end{array}$ & $\begin{array}{l}-0.16 \\
(-1.14)\end{array}$ \\
\hline General government debt & $\begin{array}{l}-0.03 \\
(-0.91)\end{array}$ & $\begin{array}{l}-0.13^{\star} \\
(-1.74)\end{array}$ & $\begin{array}{l}-0.05^{\star \star} \\
(-2.13)\end{array}$ & $\begin{array}{c}0.15^{\star} \\
(-1.97)\end{array}$ & $\begin{array}{l}-0.01 \\
(-0.24)\end{array}$ & $\begin{array}{l}-0.10 \\
(-1.09)\end{array}$ \\
\hline Net government lending & $\begin{array}{c}0.88^{\star \star \star} \\
(4.24)\end{array}$ & $\begin{array}{c}0.26 \\
(0.88)\end{array}$ & $\begin{array}{c}0.55^{\star \star \star} \\
(5.08)\end{array}$ & $\begin{array}{c}1.08^{\star \star \star} \\
(3.59)\end{array}$ & $\begin{array}{l}0.91^{\star \star} \\
(2.55)\end{array}$ & $\begin{array}{l}-0.00 \\
(-0.00)\end{array}$ \\
\hline Political stability and absence of violence/terrorism & $\begin{array}{c}4.76^{\star \star \star} \\
(2.84)\end{array}$ & $\begin{array}{c}-4.84 \\
(-1.23)\end{array}$ & $\begin{array}{c}3.83^{\star \star \star} \\
(3.00)\end{array}$ & $\begin{array}{l}-10.55 \\
(-1.56)\end{array}$ & $\begin{array}{c}3.27 \\
(1.56)\end{array}$ & $\begin{array}{l}-0.80 \\
(-0.23)\end{array}$ \\
\hline Rating & $\begin{array}{c}1.48^{\star \star \star} \\
(5.11)\end{array}$ & $\begin{array}{l}0.72^{*} \\
(1.74)\end{array}$ & $\begin{array}{c}0.23 \\
(0.83)\end{array}$ & $\begin{array}{l}1.24^{\star \star} \\
(2.19)\end{array}$ & $\begin{array}{c}1.88^{\star \star \star} \\
(6.27)\end{array}$ & $\begin{array}{c}0.59 \\
(1.05)\end{array}$ \\
\hline Lagged logarithm of total holdings & $\begin{array}{c}-1.04 \\
(-0.50)\end{array}$ & $\begin{array}{c}-2.23 \\
(-1.01)\end{array}$ & $\begin{array}{l}-3.97^{\star \star} \\
(-2.35)\end{array}$ & $\begin{array}{c}0.25 \\
(0.12)\end{array}$ & $\begin{array}{c}1.86 \\
(0.65)\end{array}$ & $\begin{array}{c}-1.11 \\
(-0.39)\end{array}$ \\
\hline Lagged percentage of sovereign holding & $\begin{array}{l}-3.25 \\
(-0.34)\end{array}$ & $\begin{array}{l}-21.35 \\
(-1.58)\end{array}$ & $\begin{array}{l}-12.66 \\
(-1.47)\end{array}$ & $\begin{array}{c}-3.18 \\
(-0.18)\end{array}$ & $\begin{array}{l}-16.35 \\
(-1.32)\end{array}$ & $\begin{array}{c}-45.52^{\star *} \\
(-2.60)\end{array}$ \\
\hline Dummy European debt crisis countries & $\begin{array}{c}6.68 \\
(1.50)\end{array}$ & $\begin{array}{l}7.22^{\star \star} \\
(2.20)\end{array}$ & $\begin{array}{l}2.14^{\star \star} \\
(2.03)\end{array}$ & $\begin{array}{l}-3.50^{\star} \\
(-1.75)\end{array}$ & $\begin{array}{c}10.41^{\star \star} \\
(2.16)\end{array}$ & $\begin{array}{c}13.54^{\star \star \star} \\
(2.77)\end{array}$ \\
\hline Dummy safe haven countries & $\begin{array}{c}6.52^{\star \star \star} \\
(4.90)\end{array}$ & $\begin{array}{c}3.65^{\star \star \star} \\
(3.18)\end{array}$ & $\begin{array}{c}3.06^{\star \star \star} \\
(3.03)\end{array}$ & $\begin{array}{c}1.54 \\
(1.19)\end{array}$ & $\begin{array}{c}7.09 \\
(1.55)\end{array}$ & $\begin{array}{c}6.06 \\
(1.41)\end{array}$ \\
\hline Constant & $\begin{array}{l}26.09 \\
(0.79)\end{array}$ & $\begin{array}{l}65.68^{\star} \\
(1.84)\end{array}$ & $\begin{array}{c}79.09^{\star \star \star} \\
(2.96)\end{array}$ & $\begin{array}{l}46.54 \\
(1.13)\end{array}$ & $\begin{array}{l}-24.18 \\
(-0.52)\end{array}$ & $\begin{array}{l}52.37 \\
(1.15)\end{array}$ \\
\hline Country fixed-effects & No & Yes & No & Yes & No & Yes \\
\hline Time fixed-effects & No & Yes & No & Yes & No & Yes \\
\hline Observations & 2,254 & 2,254 & 1,226 & 1,226 & 1,028 & 1,028 \\
\hline Adjusted $R^{2}$ & 0.18 & 0.41 & 0.13 & 0.25 & 0.31 & 0.61 \\
\hline
\end{tabular}

Note: This table represents the results of the OLS regressions and LSDV regressions. All specifications are for a minimum of 5 trades and present the results for the overall, buy and sell herding measure. The LSV herding measure is multiplied by 100, which makes the interpretation of the regression results easier.

$t$ statistics in parentheses, ${ }^{\star} p<0.10,{ }^{\star \star} p<0.05,{ }^{\star \star *} p<0.01$.

pension funds does not have an effect on pension fund herding, except for buy herding. Larger pension funds herd less intensive, which might reflect their larger in-house capacity. Furthermore, it might be an indication that smaller pension funds are more likely to follow others. The behavior of pension funds is also affected by the sovereign holdings, they already possess. In all specifications, the herd behavior is less intensive when pension funds already have substantial sovereign holdings in a country. Although, the effect is only statistically significant for sell herding. The effect is also economically significant. A one standard deviation increase in the sovereign holdings for a country lowers sell herding by 0.05 .

We find statistically significant differences in herd intensity during the European debt crisis for crisis countries. During the European debt crisis, we find substantial higher sell herding of pension funds in crisis countries. Herding increases by 0.10 in the OLS estimation and by 0.14 in the LSDV estimation, which is highly economically significant. On the buy side, we find mixed results for crisis countries. For safe havens, our findings reveal higher overall herding and higher buy herding in the OLS specification. The other estimations are statistically insignificant.

\section{Conclusions}

This study finds evidence of intensive herd behavior in the sovereign bond market by 67 large Dutch pension funds between December 2008 and December 2014. The overall, buy and sell herding measures for sovereign bonds amount to $0.14,0.12$ and 0.16 , respectively. Herding of 0.14 means that 64 percent of the pension funds' trades in one direction, and 36 percent trades in the other direction. Previous studies on the equity market found a Lakonishok et al. (1992) (LSV) herding measure of around 0.03 (Lakonishok et al., 1992, Grinblatt et al., 1995; Jame, 2011). This indicates that the intensity of herd behavior is 
approximately five times larger for bonds than for equity. More importantly, sovereign bonds account for approximately $60 \%$ of the investment portfolios of Dutch pension funds like in other countries. Thus, herd behavior in sovereign bonds may have significant consequences.

We also find different behavior of Dutch pension funds during the European debt crisis. Safe havens experience substantially higher buy herd behavior than crisis countries. Moreover, the crisis countries are confronted with much higher sell herd behavior compared to the non-crisis period and compared to safe havens. The intensity of sell herding is around 0.04 for safe havens, whereas the intensity for crisis countries ranges between 0.15 and 0.24 .

This study investigates the impact of macroeconomic and institutional factors, financial market conditions and pension characteristics on herd behavior. All these factors seem to influence herd behavior according to our quintile and regression analysis, although the effect of pension funds characteristics on herding is less pronounced. For the regression analysis, this can be explained by the averaging of pension fund characteristics on a country basis. Notwithstanding the inclusion of these variables in the regression analysis and their impact on herd behavior, we still find significantly different herd behavior during the European debt crisis. For crisis countries, our regression results reveal significantly higher sell herding.

As the potential public welfare costs of herding are high, we establish whether herd behavior exhibited by Dutch pension funds has a destabilizing effect or not. When pension funds' transitions incorporate new information, no return reversals are expected. Our findings show mixed results, when we investigate the entire sample period. Even when a distinction is made between investment and noninvestment grade bonds, or advanced and emerging and developing economies, we find mixed evidence on stabilizing behavior by Dutch pension funds. When regarding pension funds' portfolio decisions, there are return reversals in the portfolio where it is long in the most intensive buy herding quintile and short in the least intensive buy quintile.

The highest welfare costs occur during a crisis; therefore, we also investigate the European debt crisis separately. For the crisis countries, we find no evidence of destabilizing behavior by Dutch pension funds. Consequently, pension funds seem not to have aggravated the European debt crisis. In contrast, for safehaven countries, we still find mixed evidence on the effect of pension funds' herding. Generally, it seems that the contribution that pension funds make to stabilization has a higher value from a welfare perspective than destabilization during a non-crisis period or for safe havens. However, crisis periods are probably shorter than non-crisis periods. The exact social benefits or costs remain subject to further research.

Our article has some limitations. Although it uses high-frequency data (monthly data) compared to quarterly or semi-annual data as in other studies, very short-term herding may still occur. In addition, institutional trading is most likely to distort prices if it is concentrated in short intervals (Lipson and Puckett, 2010). Consequently, our estimates potentially underestimate actual herd behavior. Furthermore, our methodology does not allow us to identify the different motives of herd behavior. It is our belief that this not problematic because the outcome of herd behavior is not altered by the motive. Additionally, these motives, such as characteristic, reputational, informational and investigative herding, are highly intertwined, which makes identification of the underlying motive difficult.

Several policy recommendations follow from our results. First, this study reveals which factors influence the intensity of herd behavior, so that pension funds managers and supervisors can take this into account. Second, pension fund supervisors should not treat pension fund herd behavior as a negative phenomenon. Herd behavior may contribute to stability in the sovereign bond market during crisis times, whereas destabilizing behavior occurs during non-crisis times or for safe-haven countries which seem better equipped to handle its effects. A stricter investment policy in accordance with the strategic asset allocation may limit the destabilizing effect during non-crisis times because the limits of strategic asset allocation are more binding during crisis times than non-crisis times.

Acknowledgements. The authors thank Jack Bekooij, David Keijzer and Dirk van der Wal for their excellent research assistance. They thank the participants of the Utrecht University School of Economics seminars for their contributions, and they are grateful to the participants of the World Finance Conference in Mauritius, 25-27 July 2018, for their valuable suggestions. They are also grateful for the valuable comments of two anonymous reviewers. 


\section{References}

Afonso A, Gomes P and Rother P (2011) Short- and long-run determinants of sovereign debt credit ratings. International Journal of Finance and Economics 16, 1-15.

Andreu L, Ortiz C and Sarto JL (2014) Herding in the strategic allocations of Spanish pension plan managers. Journal of Economics and Finance 38, 658-671.

Banerjee AV (1992) A simple model of herd behavior. Quarterly Journal of Economics 107(3), 797-817.

Bank of England and the Procyclicality Working Group (2014) Procyclicality and structural trends in investment allocation by insurance companies and pension funds, July 2014.

Bauer R, Bonetti M and Broeders D (2018) Pension funds interconnections and herd behavior, DNB Working Paper, No. 612.

Bellando R (2010) Measuring Herding Intensity: A Hard Task, June 9, 2010, URL: doi:10.2139/ssrn.1622700.

Bennett JA, Sias RW and Starks LT (2003) Greener pastures and the impact of dynamic institutional preferences. The Review of Financial Studies 16(4), 1203-1238.

Bikhchandani S and Sharma S (2000) Herd Behavior in Financial Markets: A Review. IMF Working Paper, WP/00/48.

Bikhchandani S, Hirshleifer D and Welch I (1992) A theory of fads, fashion, custom, and cultural change as informational cascades. Journal of Political Economy 100(3), 709-730.

Bikker JA, Spierdijk L and Sluis PJ (2007) Market impact costs of institutional equity trades. Journal of International Money and Finance 26(6), 974-1000.

Bikker JA, Broeders D and de Dreu J (2010) Stock market performance and pension fund investment policy: rebalancing, free float, or market timing? International Journal of Central Banking 6(2), 53-79.

Borensztein ER and Gelos RG (2000) A Panic-Prone Pack? The Behavior of Emerging Market Mutual Funds. IMF Working Paper, WP/00/198.

Broeders D, Chen D, Minderhoud P and Schudel W (2021) Pension funds' herding, International Journal of Central Banking 17(1), 285-330.

Cai F, Han S, Li D and Li Y (2019) Institutional herding and its price impact: evidence from the corporate bond market. Journal of Financial Economics 131(2019), 139-167.

Calvo GA and Mendoza EG (2000) Rational contagion and the globalization of securities markets. Journal of International Economics 51, 79-113.

Cassimon D, Moreno-Dodson B and Wodon Q (2007) Debt sustainability for Low-income countries: A review of standard and alternative concepts. In Moreno-Dodson B (ed.), Public Finance for Poverty Reduction: Concepts and Case Studies From Africa and Latin America. Washington D.C.: World Bank, pp. 21-56.

Chang EC, Cheng JW and Khorana A (2000) An examination of herd behavior in equity markets: an international perspective. Journal of Banking \& Finance 24, 1651-1679.

Choe H, Kho B-C and Stulz RM (1999) Do foreign investors destabilize stock markets? The Korean experience in 1997. Journal of Financial Economics 54, 227-264.

Cooper A, Day T and Lewis C (2001) Following the leader: a study of individual analysts' earnings forecasts. Journal of Financial Economics 61, 383-416.

Dasgupta A, Prat A and Verardo M (2011) Institutional trade persistence and long-term equity returns. Journal of Finance 66(2), 635-654.

De Haan L and Kakes J (2011) Momentum or contrarian investment strategies: evidence from Dutch institutional investors. Journal of Banking \& Finance 35(9), 2245-2251.

Falkenstein EG (1996) Preferences for stock characteristics as revealed by mutual fund portfolio holdings. Journal of Finance 51(1), 111-135.

Frey S, Herbst P and Walter A (2014) Measuring mutual fund herding - A structural approach. Journal of International Financial Markets. Institutions \& Money 32, 219-239.

Froot KA, Scharfstein DS and Stein JC (1992) Herd on the street: informational inefficiencies in a market with short-term speculation. Journal of Finance 47(4), 1461-1484.

Galariotis EC, Rong W and Spyrou SI (2015) Herding on fundamental information: a comparative study. Journal of Banking \& Finance 50(2015), 589-598.

Gande A and Parsley D (2014) Sovereign Credit Ratings, Transparency and International Portfolio Flows. HKIMR Working Paper, No. 12/2014.

Gelos GR and Wei S-J (2005) Transparency and international portfolio holdings. Journal of Finance 60(6), 2987-3020.

Granger C (1998) Extracting information from mega-panels and high-frequency data. Statistica Neerlandica 52(3), 258-272.

Grinblatt M, Titman S and Wermers R (1995) Momentum investment strategies, portfolio performance, and herding: a study of mutual fund behavior. American Economic Review 85(5), 1088-1105.

Harris R and Tzavalis E (1999) Inference for unit roots in dynamic panels where the time dimension is fixed. Journal of Econometrics 91(2), 201-226.

Hirshleifer D, Subrahmanyam A and Titman S (1994) Security analysis and trading patterns when some investors receive information before others. Journal of Finance 49(5), 1665-1698. 
Holmes P, Kallinterakis V and Leite Ferreira M (2013) Herding in a concentrated market: a question of intent. European Financial Management 19(3), 497-520.

Hsieh M-F, Yang T-Y, Yang Y-T and Lee J-S (2011) Evidence of herding and positive feedback trading for mutual funds in emerging Asian countries. Quantitative Finance, 11(3), 423-435.

Hwang S and Salmon M (2004) Market stress and herding. Journal of Empirical Finance 11(4), 585-616.

Im K, Pesaran M and Shin Y (2003) Testing for unit roots in heterogeneous panels. Journal of Econometrics 115(1), 53-74.

International Monetary Fund (2014) Chapter 2: How do changes in the investor base and financial deepening affect emerging market economies? In International Monetary Fund, Global Financial Stability Report: Moving From Liquidity to Growth-Driven Markets. Washington: International Monetary Fund, pp. 67-99.

Jame R (2011) Pension Fund Herding and Stock Returns, November 2011.

Kaminsky G, Lyons RK and Schmukler SL (2004) Managers, investors, and crises: mutual fund strategies in emerging markets. Journal of International Economics 64(2004), 113-134.

Kim W and Wei S-J (2002) Foreign portfolio investors before and during a crisis. Journal of International Economics 56(2002), 77-96.

Koetsier I and Bikker JA (2017) Herding behaviour of Dutch pension funds in sovereign bond investments. DNB Working Paper, No. 569.

Koetsier I and Bikker JA (2018) Herding Behavior of Dutch Pension Funds in Asset Class Investments. DNB Working Paper, No. 602.

Lakonishok J, Shleifer A and Vishny RW (1992) The impact of institutional trading on stock prices. Journal of Financial Economics 32, 23-43.

Lipson M and Puckett A (2010) Institutional Trading During Extreme Market Movements. March 2010.

Lobão J and Serra AP (2007) Herding behavior: Evidence from Portuguese mutual funds. In Gregoriou GN (ed.), Diversification and Portfolio Management of Mutual Funds. London, UK: Palgrave Macmillan, pp. 167-197.

Melecky M and Raddatz C (2015) Fiscal responses after catastrophes and the enabling role of financial development. World Bank Economic Review 29(1), 129-149.

Nofsinger JR and Sias RW (1999) Herding and feedback trading by institutional and individual investors. Journal of Finance 54(6), 2263-2295.

Pesaran M (2007) A simple panel unit root test in the presence of cross-section dependence. Journal of Applied Econometrics 22(2), 265-312.

Puckett A and Yan X (2008) Short-term Institutional Herding and its Impact on Stock Prices. March 2008.

Raddatz C and Schmukler SL (2012) On the international transmission of shocks: micro-evidence from mutual fund portfolios. Journal of International Economics 88(2012), 357-374.

Raddatz C and Schmukler SL (2013) Deconstructing herding: evidence from pension fund investment behavior. Journal of Financial Services Research 43, 99-126.

Rajan RG (2006) Has finance made the world riskier? European Financial Management 12(4), 499-533.

Scharfstein DS and Stein JC (1990) Herd behavior and investment. American Economic Review 80(3), 465-479.

Sias RW (2004) Institutional herding. Review of Financial Studies 17(1), 165-206.

Teh LL and DeBondt WFM (1997) Herding behavior and stock returns: an exploratory investigation. Swiss Journal of Economics and Statistics 133, 293-324.

Trueman B (1994) Analyst forecasts and herding behavior. The Review of Financial Studies 7(1), 97-124.

Voronkova S and Bohl MT (2005) Institutional traders' behavior in an emerging stock market: empirical evidence on polish pension fund investors. Journal of Business Finance \& Accounting 32(7 \& 8), 1537-1560.

Wermers R (1999) Mutual fund herding and the impact on stock prices. Journal of Finance 54(2), 581-622.

Wylie S (2005) Fund manager herding: a test of the accuracy of empirical results using U.K. data. Journal of Business $78(1)$, 381-403.

Xiao Y (2007) What do bond holdings reveal about international funds' preferences? Emerging Markets Review 8(2007), $167-180$.

Xiao J (2015) Domestic and Foreign Mutual Funds in Mexico: Do They Behave Differently? IMF Working Paper, $\mathrm{WP} / 15 / 104$

Cite this article: Koetsier I, Bikker JA (2022). Herd behavior of pension funds in sovereign bond investments. Journal of Pension Economics and Finance 21, 475-501. https://doi.org/10.1017/S1474747221000202 